\title{
Oncobiosis and Microbial Metabolite Signaling in Pancreatic Adenocarcinoma
}

\author{
Borbála Kiss ${ }^{1}$, Edit Mikó ${ }^{2}$, Éva Sebő ${ }^{3}$, Judit Toth ${ }^{1}$, Gyula Ujlaki ${ }^{2}$, Judit Szabó ${ }^{4}$, Karen Uray ${ }^{2}$ (D) \\ Péter Bai ${ }^{2,5,6, *(\mathbb{D})}$ and Péter Árkosy ${ }^{1, *}$ \\ 1 Departments of Oncology, University of Debrecen, 4032 Debrecen, Hungary; bkiss@med.unideb.hu (B.K.); \\ tothjuditdr11@t-online.hu (J.T.) \\ 2 Departments of Medical Chemistry, University of Debrecen, 4032 Debrecen, Hungary; \\ miko.edit@med.unideb.hu (E.M.); ujlaki.gyula@med.unideb.hu (G.U.); karen.uray@med.unideb.hu (K.U.) \\ 3 Kenézy Breast Center, Kenézy Gyula County Hospital, 4032 Debrecen, Hungary; seboeva@gmail.com \\ 4 Medical Microbiology Faculty of Medicine, University of Debrecen, 4032 Debrecen, Hungary; \\ szabjud@med.unideb.hu \\ 5 MTA-DE Lendület Laboratory of Cellular Metabolism, 4032 Debrecen, Hungary \\ 6 Research Center for Molecular Medicine, Faculty of Medicine, University of Debrecen, \\ 4032 Debrecen, Hungary \\ * $\quad$ Correspondence: baip@med.unideb.hu (P.B.); arkosy.peter@med.unideb.hu (P.Á.); Tel.: +36-52-412-345 (P.B.); \\ +36-52-255-840 (P.Á.); Fax: +36-52-412-566 (P.B.); +36-52-255-657 (P.Á.)
}

Received: 31 March 2020; Accepted: 23 April 2020; Published: 25 April 2020

\begin{abstract}
Pancreatic adenocarcinoma is one of the most lethal cancers in both men and women, with a median five-year survival of around $5 \%$. Therefore, pancreatic adenocarcinoma represents an unmet medical need. Neoplastic diseases, such as pancreatic adenocarcinoma, often are associated with microbiome dysbiosis, termed oncobiosis. In pancreatic adenocarcinoma, the oral, duodenal, ductal, and fecal microbiome become dysbiotic. Furthermore, the pancreas frequently becomes colonized (by Helicobacter pylori and Malassezia, among others). The oncobiomes from long- and short-term survivors of pancreatic adenocarcinoma are different and transplantation of the microbiome from long-term survivors into animal models of pancreatic adenocarcinoma prolongs survival. The oncobiome in pancreatic adenocarcinoma modulates the inflammatory processes that drive carcinogenesis. In this review, we point out that bacterial metabolites (short chain fatty acids, secondary bile acids, polyamines, indole-derivatives, etc.) also have a role in the microbiome-driven pathogenesis of pancreatic adenocarcinoma. Finally, we show that bacterial metabolism and the bacterial metabolome is largely dysregulated in pancreatic adenocarcinoma. The pathogenic role of additional metabolites and metabolic pathways will be identified in the near future, widening the scope of this therapeutically and diagnostically exploitable pathogenic pathway in pancreatic adenocarcinoma.
\end{abstract}

Keywords: pancreatic adenocarcinoma; oncobiome; microbiome; bile acids; bacterial metabolite; amino acid metabolites; polyamines; LPS; short chain fatty acid

\section{Pancreatic Adenocarcinoma, an Unmet Medical Need}

Pancreatic adenocarcinoma stems from the exocrine glands and ducts of the pancreas and usually appears in the head of the pancreas (2/3 of cases). Pancreatic adenocarcinoma is the fourth most prevalent cancer with the highest mortality in both men and women [1]. Worldwide, in 2018, 458,918 cases were reported, and 432,242 deaths were estimated to be linked to pancreatic adenocarcinoma [2]. The number of pancreatic adenocarcinoma cases has continued to rise [3] and is predicted to rise even more sharply in the future [4]. The five-year survival for pancreatic adenocarcinoma is around $5 \%$, as the disease progresses asymptomatically to the locally advanced or metastatic stages, reducing 
therapeutic effectiveness [1]. Thus, late diagnosis and a low five-year survival rate represent an unmet medical need in pancreatic adenocarcinoma.

Curative surgical treatment can only be achieved in $15-20 \%$ of patients with pancreatic adenocarcinoma, due to the spreading of the disease around blood vessels, rendering patients inoperable. Neoadjuvant therapy can reduce tumor size and enable surgical excision. The chemotherapy regimen to combat pancreatic adenocarcinoma includes nucleoside analogs (gemcitabine, capecitabine), antimetabolites (5-fluorouracil), topoisomerase inhibitors (irinotecan), taxanes (Nanoparticle albumin-bound (NAB)-paclitaxel), and platinum compounds (oxaliplatin) [5]. Combinatorial chemotherapies are organized into regimens known as FOLFIRINOX (Folinic Acid-Fluorouracil-Irinotecan-Oxaliplatin) and FOLFOX (Folinic acid-Fluorouracil-Oxaliplatin) [5]. There are also new chemotherapy modalities on the way (e.g., Poly(ADP-ribose) polymerase (PARP) inhibitors [6]). Chemotherapy can be complemented by radiotherapy; however, evidence supporting the use of radiotherapy is very scarce. The treatment of pancreatic adenocarcinoma calls for a multidisciplinary approach especially in patients undergoing neoadjuvant therapy [7].

Environmental risk factors for pancreatic adenocarcinoma include smoking, alcoholism, chronic or recurrent pancreatitis, obesity, and diabetes mellitus [8]. Genetic mutations are also associated with pancreatic adenocarcinoma [9]. Mutations in KRAS were identified in approximately $80 \%$ of pancreatic adenocarcinoma cases [10]. Recent studies associated other mutations with pancreatic adenocarcinoma, including BRCA1, TP53, and a set of other DNA repair factors [9].

\section{The Oncobiotic Transformation of the Microbiome}

The microbiome shows characteristic changes in neoplastic diseases; the transformed microbiome, a characteristic of neoplasia, is termed the oncobiome [11-18]. Recent advances demonstrate that the oncobiome has a pathogenic role in neoplasia. An intricate relationship develops between the microbiome and the host, where the host can influence the composition and biomass of the microbiome through its behavior, feeding, and immune system, while the microbiome impacts on the host through secreting microbial metabolites, as well as serving as bait for the immune system [19-30].

Hanahan and Weinberg [31,32] coined the term "cancer hallmark", which refers to a collection of biological processes that drive oncogenesis and support the unlimited proliferation of cancer cells. The oncobiome plays either a direct or tangential role in regulating all cancer hallmarks. The oncobiome is definitively involved in avoiding immune destruction, enhancing tumor promoting inflammation, activating movement, invasion, and metastasis, inducing angiogenesis, inducing genome instability and mutations, and deregulating cellular energetics [21-24,26-30,33-35].

Sustained inflammation and the consequent oxidative stress can lead to DNA damage and genomic instability, which are risk factors for accumulating mutations and, subsequently, for carcinogenic transformation [36-38]. A dysbiotic microbiome can drive local inflammation and, therefore, can be a driver of carcinogenesis, including pancreatic adenocarcinoma [39-43]. In contrast, increased oxidative stress can be cytostatic in certain malignancies, such as breast cancer [34,38]. In other words, oxidative stress, induced by oncobiosis, can induce malignancies, but in later stages can have cytostatic properties.

The oncobiome usually has a different immunogenic character than the normal microbiome (eubiome), as oncobiosis alters the immune system [21]. The tolerogenic character of the immune system inhibits the early elimination of cancer cells [21]. A more immunogenic microbiome supports immunotherapy/targeted therapy $[27,44]$, while sustained, high-level inflammation can promote carcinogenesis [24,39-43]. In this process, the actual physical presence of the bacteria seems to be a key factor, but immunomodulatory bacterial metabolites are also important [23].

Several studies have shown that oncobiotic transformation supports cellular proliferation, invasion, and metastasis [22-25]. In addition, oncobiosis changes the expression of vascular-endothelial growth factor (VEGF) [23], implying that oncobiosis is involved in the regulation of tumor vascularization. To date, published studies show that these processes are the main targets of oncobiosis and oncobiotic bacterial metabolites. 
What are the elementary steps behind these processes? Bacterial metabolites modulate the redox balance of cancer cells [24,34], as well as cancer cell metabolism [22,23]. These processes culminate in cytostasis, a reprogramming of the epithelial-mesenchymal transition leading to decreased cancer stem cells $[22-25,29,34,35,45]$. These basic events are the pillars for the inhibition of cancer cell growth, movement, and metastasis formation [46-48].

What can cause oncobiotic transformation or, in general, changes to the microbiome? Among the factors inducing oncobiosis, lifestyle plays a key role, including activities such as smoking [49], diet, obesity [50], changes to the diurnal rhythm [51-53], aging [54-56], underlying diseases such as diabetes [57], and exercise [58]. In fact, these factors are all individual risk factors for pancreatic adenocarcinoma. In cancers, other than pancreatic adenocarcinoma, antibiotic [59] and probiotic use $[60,61]$ are also associated with carcinogenesis.

\section{The Oncobiome in Pancreatic Adenocarcinoma}

The relationship between the microbiome and pancreatic adenocarcinoma was first suggested by the discovery that Helicobacter pylori colonization was associated with pancreatitis [62]. This was followed by the discovery of associations between the oral [63], gut [64], pancreas [41,65,66], and fecal $[43,67]$ microbiomes, the mycobiome [68], and pancreatic cancer. Since then, there has been an immense expansion of oncobiome studies focused on pancreatic adenocarcinoma.

According to our current understanding, elements of the oral, gastric, and intestinal microbiome can drive inflammation, which is a risk factor for carcinogenesis in the pancreas. In brief, the oral, gastric, and duodenal flora can colonize the common duct, the bile duct, and the pancreatic duct and, finally, the pancreas itself, as shown in a series of animal and human studies [39,64,66,69-80]. Characteristic changes occur to the oral $[63,81-88]$ and duodenal microbiome [64] in pancreatic adenocarcinoma. Enterobacter, Enterococcus, and E. coli bactibilia [78] or the colonization of the pancreas [41,65,68,89-94] are risk factors for pancreatic adenocarcinoma. Of note, an oncogenic role of hepatotropic viruses (Hepatitis B and C virus and Transfusion Transmitted/Torque Teno virus) in pancreatic adenocarcinoma has been observed in a clinical setting, although the exact molecular mechanisms are yet unknown [78]. Similarly, changes to the mycobiome were also reported in pancreatic adenocarcinoma [68]. In a murine genetic model ( $\mathrm{Kas}^{-/-}$ Tp53-l- model), the food microbiome can also invade the pancreas [41]. The pathogenic role of bacterial invasion in the pancreas was demonstrated by the decreased incidence of pancreatic adenocarcinoma in gnotobiotic or antibiotic-treated mice [65]. Similar issues were raised in conjunction with human premedication before surgery in pancreatic carcinoma patients [92]. There seems to be a specificity among the antibiotics. For instance, penicillin increased the risk for pancreatic adenocarcinoma [95], while broad range antibiotic cocktails (streptomycin, gentamicin, bacitracin, and ciprofloxacin [65] or ampicillin, vancomycin, neomycin, and metronidazole [96]) were protective in murine models [97]. Furthermore, fecal microbiome transplantation modulates susceptibility to the disease [41,91].

The main findings concerning the oncobiome in pancreatic adenocarcinoma are summarized in Table 1. There is no consensus on how the diversity of the microbiome changes in pancreatic adenocarcinoma. The alpha diversity (Shannon index) of the tongue microbiome increases [86]. In contrast, the saliva microbiome showed no change in alpha diversity, while beta diversity was different between cases and controls [88]. There was a tendency towards a lower alpha index (Operational taxonomic unit (OTU) diversity) in the duodenum of pancreatic adenocarcinoma patients [64]. The alpha diversity (Chao1, Shannon) of the pancreatic microbiome differed between cases and controls, but the change was not consequent in the study of Pushalkar et al. [41] (also similar to the findings of [87] and [65]). The pancreatic mycobiome alpha diversity (OTU, Shannon) decreased [68] in pancreatic adenocarcinoma patients. Nevertheless, alpha diversity indices in patients with long-term survival were higher than short-term survival [91]. The alpha diversity of the stool microbiome in patients with adenocarcinoma was lower in two studies $[43,94]$. (For the explanation of the diversity indices we refer the reader to the following references $[98,99])$. 
Table 1. The main findings of the human oncobiome studies in pancreatic adenocarcinoma.

\begin{tabular}{|c|c|c|c|c|}
\hline Sample Type and Sample Size & Method & Changes to Microbiome & Other Observations & Ref. \\
\hline \multicolumn{5}{|c|}{ Changes to the oral microbiome } \\
\hline $\begin{array}{l}\text { 11,328 individuals in a prospective study. Dental } \\
\text { health was monitored between 1971-1992 }\end{array}$ & & & $\begin{array}{l}\text { Periodontitis increases the risk for pancreatic } \\
\text { adenocarcinoma. }\end{array}$ & [81] \\
\hline $\begin{array}{l}10 \text { resectable patients with pancreatic cancer and } \\
10 \text { matched healthy controls for oral microbiome } \\
\text { assay, } 28 \text { resectable pancreatic cancer, } 28 \text { matched } \\
\text { healthy controls, and } 27 \text { chronic pancreatitis } \\
\text { samples for validation }\end{array}$ & HOMIM hybridization array & $\begin{array}{l}\text { Streptococci, Veilonella, Actinobacteria, } \\
\text { Campylobacter, and Prevotella increased in } \\
\text { pancreatic adenocarcinoma patients. }\end{array}$ & $\begin{array}{c}\text { Neisseria elongata and Streptococcus mitis were } \\
\text { validated as biomarkers for pancreatic } \\
\text { adenocarcinoma. }\end{array}$ & [63] \\
\hline $\begin{array}{l}\text { Pre-diagnosis blood samples from } 405 \text { pancreatic } \\
\text { cancer cases and } 416 \text { matched controls, collected as } \\
\text { part of the European Prospective Investigation into } \\
\text { Cancer and Nutrition study }\end{array}$ & & & $\begin{array}{l}\text { High serum antibodies against Porphyromonas } \\
\text { gingivalis ATTC } 53978 \text { showed a two fold increase } \\
\text { in risk for pancreatic adenocarcinoma. Those } \\
\text { individuals who had high antibody titer against } \\
\text { the commensal flora had a lower risk for } \\
\text { pancreatic adenocarcinoma as compared to those } \\
\text { with low titer. }\end{array}$ & [82] \\
\hline $\begin{array}{c}8 \text { pancreatic adenocarcinoma patients and } 22 \\
\text { healthy controls }\end{array}$ & $\begin{array}{l}\text { 16S rDNA was amplified and } \\
\text { sequenced }\end{array}$ & $\begin{array}{l}\text { The pancreatic cancer group had higher levels } \\
\text { of Leptotrichia, and lower levels of } \\
\text { Porphyromonas, and Neisseria. No difference in } \\
\text { diversity. Leptotrichia to Porphyromonas ratio } \\
\text { was significantly higher in pancreatic } \\
\text { adenocarcinoma patients. }\end{array}$ & & [83] \\
\hline $\begin{array}{l}361 \text { incident pancreatic adenocarcinoma patients } \\
\text { and } 371 \text { matched controls from two prospective } \\
\text { cohort studies, the American Cancer Society } \\
\text { Cancer Prevention Study II and the National } \\
\text { Cancer Institute Prostate, Lung, Colorectal and } \\
\text { Ovarian Cancer Screening Trial. }\end{array}$ & $\begin{array}{c}\text { DNA was isolated from oral } \\
\text { wash samples; } 16 \mathrm{~S} \text { rRNA gene } \\
\text { V3-V4 was amplified and } \\
\text { sequenced using Roche } 454 \mathrm{FLX} \\
\text { Titanium Pyrosequencing } \\
\text { system }\end{array}$ & $\begin{array}{l}\text { Carriage of Porphyromonas gingivalis and } \\
\text { Aggregatibacter actinomycetemcomitans were } \\
\text { associated with a higher risk for pancreatic } \\
\text { adenocarcinoma. Fusobacteria and its genus, } \\
\text { Leptotrichia decreased the risk of pancreatic } \\
\text { adenocarcinoma. The genus Alloprevotella } \\
\text { increased the risk for pancreatic } \\
\text { adenocarcinoma. }\end{array}$ & & [85] \\
\hline $\begin{array}{c}30 \text { stage I pancreas head adenocarcinoma patients } \\
\text { and } 25 \text { healthy controls }\end{array}$ & $\begin{array}{l}\text { Tongue scrapes were collected } \\
\text { and the V3-V4 } 16 \mathrm{~S} \text { rDNA was } \\
\text { amplified and sequenced }\end{array}$ & $\begin{array}{l}\text { Leptotrichia, Fusobacterium, Rothia, Actinomyces, } \\
\text { Corynebacterium, Atopobium, Peptostreptococcus, } \\
\text { Catonella, Oribacterium, Filifactor, Campylobacter, } \\
\text { Moraxella, and Tannerella were overrepresented, } \\
\text { while Haemophilus, Porphyromonas, and } \\
\text { Paraprevotella were underrepresented in } \\
\text { pancreatic adenocarcinoma patients. }\end{array}$ & $\begin{array}{l}\text { Haemophilus, Porphyromonas, Leptotrichia, and } \\
\text { Fusobacterium distinguished pancreatic } \\
\text { adenocarcinoma patients from healthy subjects. }\end{array}$ & [86] \\
\hline
\end{tabular}


Table 1. Cont.

\begin{tabular}{|c|c|c|c|c|}
\hline Sample Type and Sample Size & Method & Changes to Microbiome & Other Observations & Ref. \\
\hline $\begin{array}{l}\text { Saliva samples from } 280 \text { pancreatic } \\
\text { adenocarcinoma cases ( } 29 \text { stage I, } 160 \text { stage II, } 37 \\
\text { stage III, and } 54 \text { stage IV pancreatic tumors) of } \\
\text { which } 273 \text { was used in the study and } 285 \text { controls }\end{array}$ & $\begin{array}{l}\text { V4 region of the } 16 \mathrm{~S} \text { rRNA gene } \\
\text { was PCR amplified and } \\
\text { sequencing was performed on } \\
\text { the Illumina MiSeq. }\end{array}$ & $\begin{array}{c}\text { Haemophilus genus showed a marginal } \\
\text { association with pancreatic cancer risk. } \\
\text { Enterobacteriaceae, Lachnospiraceae, } \\
\text { Bacteroidaceae, and Staphylococcaceae showed a } \\
\text { positive correlation with pancreatic cancer risk. }\end{array}$ & & {$[88]$} \\
\hline \multicolumn{5}{|c|}{ Helicobacter pylori colonization (seropositivity) } \\
\hline $\begin{array}{l}\text { Cases with pancreatic cancer }(n=87) \text { were } \\
\text { matched to controls }(n=263) \text { using age, sex and } \\
\text { time for baseline investigation as } \\
\text { matching variables }\end{array}$ & $\begin{array}{l}\text { H. pylori serology was analyzed } \\
\text { in stored serum samples using } \\
\text { an enzyme-linked } \\
\text { immunosorbent assay }\end{array}$ & & $\begin{array}{c}\text { H. pylori seropositivity was not associated with } \\
\text { pancreatic cancer in the total cohort (adjusted OR } \\
1.25(0.75-2.09)) \text {. However, a statistically } \\
\text { significant association was found in never smokers } \\
\text { (OR } 3.81 \text { (1.06-13.63) adjusted for alcohol } \\
\text { consumption) and a borderline statistically } \\
\text { significant association was found in subjects with } \\
\text { low alcohol consumption (OR } 2.13(0.97-4.69) \\
\text { adjusted for smoking). }\end{array}$ & [62] \\
\hline 110 patients with pancreatic cancer & $\begin{array}{l}\text { A polypeptide antibody against } \\
\text { the plasminogen-binding } \\
\text { protein (PBP) of Helicobacter } \\
\text { pylori and with the } \\
\text { ubiquitin-protein ligase E3 } \\
\text { component, n-recognin 2 } \\
\text { (UBR2), an enzyme highly } \\
\text { expressed in acinar cells of the } \\
\text { pancreas }\end{array}$ & & $\begin{array}{l}\text { The antibody was positive in } 5 \text { of } 110 \text { patients with } \\
\text { pancreatic cancer }(5 \%) \text {. }\end{array}$ & [69] \\
\hline $\begin{array}{l}\text { Venipuncture specimens were obtained from a } \\
\text { representative sample of } 761 \text { case patients and } 794 \\
\text { randomly selected control subjects matched by } \\
\text { category of age and gender }\end{array}$ & $\begin{array}{l}\text { Antibody seropositivity for } H \text {. } \\
\text { pylori and its virulence protein } \\
\text { CagA were determined by } \\
\text { commercial enzyme-linked } \\
\text { immunosorbent IgG assays }\end{array}$ & & $\begin{array}{c}\text { Compared with individuals seronegative for both } \\
\text { H. pylori and CagA, decreased pancreas-cancer risk } \\
\text { was seen for CagA seropositivity [adjusted OR, } \\
0.68 \text {; } 95 \% \text { confidence interval (CI), } 0.54-0.84] \text {, } \\
\text { whereas some increased risk was suggested for } \\
\text { CagA-negative H. pylori seropositivity (OR, 1.28; } \\
\text { 95\% CI, 0.76-2.13). }\end{array}$ & {$[70]$} \\
\hline \multicolumn{5}{|c|}{ Changes to the duodenal microbiome } \\
\hline $\begin{array}{c}14 \text { patients with pancreatic head cancer and } 14 \\
\text { healthy controls. } \\
\text { Endoscopic duodenal mucosal biopsies }\end{array}$ & $\begin{array}{l}\text { 16S rRNA gene pyrosequencing } \\
\text { after the PCR amplification of } \\
\text { the V3-V4 region. The } \\
\text { rarefaction curves did not } \\
\text { approach a plateau. }\end{array}$ & $\begin{array}{l}\text { Acinetobacter, Aquabacterium, Oceanobacillus, } \\
\text { Rahnella, Massilia, Delftia, Deinococcus, and } \\
\text { Sphingobium were more abundant in the } \\
\text { duodenal mucosa of pancreatic cancer patients, } \\
\text { whereas the duodenal microbiomes of healthy } \\
\text { controls were enriched with Porphyromonas, } \\
\text { Paenibacillus, Enhydrobacter, Escherichia, Shigella, } \\
\text { and Pseudomonas. Alpha and beta diversity } \\
\text { were not different between the two groups. }\end{array}$ & $\begin{array}{l}\text { Pancreatic adenocarcinoma patients have a higher } \\
\text { incidence of } H \text {. pylori colonization. }\end{array}$ & [64] \\
\hline
\end{tabular}


Table 1. Cont.

\begin{tabular}{|c|c|c|c|c|}
\hline Sample Type and Sample Size & Method & Changes to Microbiome & Other Observations & Ref. \\
\hline \multicolumn{5}{|c|}{ Changes to the pancreatic microbiome } \\
\hline $\begin{array}{l}283 \text { patients with pancreatic ductal } \\
\text { adenocarcinoma (PDAC) }\end{array}$ & $\begin{array}{l}\text { Genomic DNA extracted from } \\
\text { FFPE tissue specimens assessed } \\
\text { using TaqMan primer/probe sets } \\
\text { to detect Fusobacterium species }\end{array}$ & & $\begin{array}{l}\text { 8.8\% detection rate of Fusobacterium species in } \\
\text { pancreatic cancers; however, tumor Fusobacterium } \\
\text { status was not associated with any clinical and } \\
\text { molecular features. In multivariate Cox regression } \\
\text { analysis, compared with the Fusobacterium } \\
\text { species-negative group, higher cancer-specific } \\
\text { mortality rates were observed in the Fusobacterium } \\
\text { positive group. }\end{array}$ & [89] \\
\hline $\begin{array}{l}\text { Human FFPE pancreatic adenocarcinoma samples } \\
\qquad(n=27)\end{array}$ & $\begin{array}{l}\text { Illumina sequencing of V1-V3 } \\
\text { hypervariable regions of } 16 \mathrm{~S} \\
\text { RNA gene. }\end{array}$ & $\begin{array}{l}\text { Differential presence of Acinetobacter, Afipia, } \\
\text { Corynebacterium, Deltia, Enterobacter, } \\
\text { Enterococcus, Escherichia, Klebsiella, } \\
\text { Propionibacterium, Pseudomonas, Rastoria, } \\
\text { Sphingomonas, Staphylococcus, and Streptococcus } \\
\text { between healthy, pancreatitis, and pancreatic } \\
\text { adenocarcinoma tissues. }\end{array}$ & $\begin{array}{l}\text { In the pancreas, the microbiome could not } \\
\text { discriminate between healthy, pancreatitis, and } \\
\text { pancreatic adenocarcinoma states. } \\
\text { Culturable bacteria are present in the human } \\
\text { pancreas with a mean of } \sim 1 \times 10^{5} \text { (aerobic) and } \\
\sim 1 \times 10^{5} \text { (anaerobic) cfu/g of tissue after } 48 \mathrm{~h} \\
\text { of culture. }\end{array}$ & [65] \\
\hline $\begin{array}{l}\text { Pancreatic juice from pancreatic cancer }(n=20) \text { and } \\
\text { duodenal cancer/bile duct cancer }(n=16) \text { patients }\end{array}$ & $\begin{array}{l}\text { PCR identification of bacterial } \\
\text { species by } 16 \mathrm{~S} \text { ribosomal } \\
\text { RNA gene. }\end{array}$ & $\begin{array}{l}\text { Enterococcus faecalis may be involved in } \\
\text { pancreas carcinogenesis. }\end{array}$ & $\begin{array}{l}\text { E. faecalis is present in pancreas tissue in cancer } \\
\text { patients. Antibodies against } E \text {. faecalis capsular } \\
\text { polysaccharide is elevated in chronic } \\
\text { pancreatitis patients. }\end{array}$ & [90] \\
\hline $\begin{array}{c}\text { Patients with pancreatic adenocarcinoma }(n=32), \\
\text { matched healthy individuals }(n=31) . \\
\text { stool and pancreas tissue were assessed }\end{array}$ & $\begin{array}{l}\text { Sequencing of the V3-V4 } \\
\text { hypervariable region of the } 16 \mathrm{~S} \\
\text { RNA gene after PCR } \\
\text { amplification }\end{array}$ & $\begin{array}{l}\text { Proteobacteria are more abundant in patients } \\
\text { with pancreatic adenocarcinoma as compared } \\
\text { to gut cancer patients. }\end{array}$ & & [41] \\
\hline $\begin{array}{l}105 \text { subjects were enrolled of which } 27 \text { had } \\
\text { pancreatic adenocarcinoma, } 57 \text { had intraductal } \\
\text { papillary mucinous neoplasms and } 21 \text { had } \\
\text { benign lesions }\end{array}$ & $\begin{array}{l}\text { Pancreas cyst fluid was } \\
\text { collected, total bacterial } 16 \mathrm{~S} \\
\text { copy number was assessed, and } \\
\text { 16S DNA was sequenced }\end{array}$ & $\begin{array}{l}\text { Fusobacterium nucleatum and Granulicatella } \\
\text { adiacens were associated with high-grade } \\
\text { dysplasia. In network analysis, the network's } \\
\text { nodes were Actinobacteria (Cutibacterium acnes), } \\
\text { Bacteroidetes, Firmicutes (Streptococcus anginous, } \\
\text { Granulicatella adiacens), and Proteobacteria } \\
\text { (Klebsiella aerogenes). }\end{array}$ & $\begin{array}{l}\text { The number of } 16 \mathrm{~S} \text { reads increases in precancerous } \\
\text { and cancer cases. }\end{array}$ & [87] \\
\hline $\begin{array}{l}\text { Human fecal samples and specimens of pancreatic } \\
\text { tissue were collected under sterile conditions from } \\
\text { healthy volunteers and patients undergoing } \\
\text { surgery for PDA or pancreatic endocrine tumors } \\
\text { (benign disease) }\end{array}$ & $\begin{array}{l}\text { PCR amplification and } \\
\text { sequencing of the ITS1 region of } \\
\text { the } 18 \mathrm{~S} \text { rRNA gene using } \\
\text { Illumina sequencing }\end{array}$ & $\begin{array}{l}\text { Pancreatic adenocarcinoma tumors with fungal } \\
\text { infiltration were enriched for Malassezia spp. }\end{array}$ & $\begin{array}{l}\text { Ligation of mannose-binding lectin (MBL), which } \\
\text { binds to glycans of the fungal wall to activate the } \\
\text { complement cascade, was required for } \\
\text { oncogenic progression. }\end{array}$ & [68] \\
\hline $\begin{array}{l}\text { Long-term surviving }(n=22) \text { and short-term } \\
\text { surviving }(n=21) \text { pancreatic } \\
\text { adenocarcinoma patients. }\end{array}$ & $\begin{array}{l}\text { From the tumor and feces } 16 S \\
\text { rDNA V4 region was amplified } \\
\text { by PCR and sequenced in the } \\
\text { MiSeq platform (Illumina). }\end{array}$ & $\begin{array}{l}\text { Intratumoral microbiome signature } \\
\text { (Pseudoxanthomonas-Streptomyces- } \\
\text { Sacharopolyspora-Bacillus clausii) is highly } \\
\text { predictive of long-term survivorship. }\end{array}$ & $\begin{array}{l}\text { The microbiome that provides long-term survival } \\
\text { can be transplanted. }\end{array}$ & [91] \\
\hline
\end{tabular}


Table 1. Cont

\begin{tabular}{|c|c|c|c|c|}
\hline Sample Type and Sample Size & Method & Changes to Microbiome & Other Observations & Ref. \\
\hline $\begin{array}{l}50 \text { patients with pancreatic adenocarcinoma were } \\
\text { enrolled. In cases where a biliary stent was } \\
\text { inserted prior to surgery, the stent was removed } \\
\text { and cultured. In other cases, swabs of bile or } \\
\text { pancreatic fluid and tissue from the bile duct or } \\
\text { pancreas were obtained and cultured. }\end{array}$ & Classical culture & $\begin{array}{l}96 \% \text { of the specimens demonstrated the } \\
\text { presence of microbes, } 90 \% \text { of all cases were } \\
\text { polymicrobial. The most frequent species } \\
\text { found were Enterobacteriaceae, Enterococcus } \\
\text { species, Candida species, and } \\
\text { Streptococcus milleri }\end{array}$ & & [92] \\
\hline $\begin{array}{l}152 \text { Italian patients of which } 72 \text { had pancreas head } \\
\text { adenocarcinoma patients were present }\end{array}$ & Classical culture & $\begin{array}{l}\text { The most common bacteria among pancreas } \\
\text { head adenocarcinoma patients were } E \text {. coli, } K \text {. } \\
\text { pneumoniae, and P. aeruginosa, and less } \\
\text { frequently, Alcaligenes spp., Serratia spp., and } \\
\text { Enterococcus spp. }\end{array}$ & $\begin{array}{l}\text { Although pancreas head carcinoma patients were } \\
\text { not assessed separately, only such patients were } \\
\text { present in the shortest survival cohort enabling the } \\
\text { assessment of that patient population. E. coli, K. } \\
\text { pneumoniae, and P. aeruginosa showed a high } \\
\text { percentage of resistance to third-generation } \\
\text { cephalosporins (3GCs), aminoglycosides class, and } \\
\text { quinolone group, especially to levofloxacin, but } \\
\text { the same bacteria were sensitive to carbapenems. }\end{array}$ & [93] \\
\hline $\begin{array}{l}50 \text { patients with pancreatic adenocarcinoma, } 34 \\
\text { other organs (i.e., controls). In total, } 189 \text { tissue } \\
\text { samples (pancreatic duct, duodenum, pancreas), } \\
57 \text { swabs (bile duct, jejunum, stomach), and } 12 \\
\text { stool samples. }\end{array}$ & $\begin{array}{c}\text { The } 16 \mathrm{~S} \text { rRNA V3-V4 } \\
\text { hypervariable regions were } \\
\text { amplified using Illumina MiSeq }\end{array}$ & $\begin{array}{l}\text { Lactobacillus ssp. was significantly higher in } \\
\text { noncancer subjects compared with cancer } \\
\text { subjects and the relative abundance of } \\
\text { Fusobacterium spp was higher in cancer subjects } \\
\text { compared with noncancer subjects. }\end{array}$ & & [94] \\
\hline \multicolumn{5}{|c|}{ Changes to stool microbiome } \\
\hline $\begin{array}{c}\text { Prospective study, } 85 \text { pancreatic cancer (PC) and } 57 \\
\text { matched healthy controls (HC) }\end{array}$ & MiSeq sequencing & $\begin{array}{l}\text { Phylum Bacteroidetes was significantly } \\
\text { increased, while Firmicutes and Proteobacteria } \\
\text { were decreased in PC patients versus } \\
\text { healthy controls. }\end{array}$ & $\begin{array}{l}\text { Gut microbial diversity decreased in pancreatic } \\
\text { adenocarcinoma. Alpha diversity decreased. The } \\
\text { abundance of certain pathogens and } \\
\text { lipopolysaccharides-producing bacteria increased. } \\
\text { Probiotics and butyrate-producing bacteria } \\
\text { decreased. Changes to the microbiome can be used } \\
\text { as markers to detect pancreatic adenocarcinoma } \\
\text { and the obstructive and non-obstructive forms. }\end{array}$ & [43] \\
\hline $\begin{array}{l}\text { Patients with pancreatic adenocarcinoma }(n=32), \\
\text { and matched healthy individuals }(n=31) . \\
\text { stool and pancreatic tissue were assessed }\end{array}$ & $\begin{array}{l}\text { Sequencing of the V3-V4 } \\
\text { hypervariable region of the } 16 \mathrm{~S} \\
\text { RNA gene after PCR } \\
\text { amplification }\end{array}$ & $\begin{array}{l}\text { Proteobacteria are more abundant in patients } \\
\text { with pancreatic adenocarcinoma as compared } \\
\text { to healthy controls. }\end{array}$ & & [41] \\
\hline $\begin{array}{l}\text { Long-term surviving }(n=22) \text { and short-term } \\
\text { surviving }(n=21) \text { patients. Sequencing of } \\
\text { intratumor and stool microbiomes. }\end{array}$ & $\begin{array}{l}16 \mathrm{~S} \text { rDNA V4 region was } \\
\text { amplified by PCR and } \\
\text { sequenced in the MiSeq } \\
\text { platform (Illumina). }\end{array}$ & $\begin{array}{l}\text { Intra-tumoral microbiome signature occurs in } \\
\text { pancreatic adenocarcinoma patients } \\
\text { (Pseudoxanthomonas-Streptomyces- } \\
\text { Saccharopolyspora-Bacillus clausii) that is highly } \\
\text { predictive of long-term survivorship. }\end{array}$ & $\begin{array}{l}\text { The microbiome that provides long-term survival } \\
\text { can be transplanted. }\end{array}$ & [91] \\
\hline $\begin{array}{c}30 \text { patients with pancreatic adenocarcinoma, } 6 \\
\text { patients with pre-cancerous lesions, } 13 \text { healthy } \\
\text { subjects, and } 16 \text { with non-alcoholic fatty } \\
\text { liver disease }\end{array}$ & $\begin{array}{l}\text { 16S RNA was PCR amplified } \\
\text { and was sequenced using the } \\
\text { Illumina MiSeq platform and } \\
\text { LEfSe linear discriminant } \\
\text { analysis (LDA) was performed }\end{array}$ & & $\begin{array}{l}\text { Patterns of the microbiome can separate pancreatic } \\
\text { adenocarcinoma patients from healthy subjects } \\
\text { and patients with comorbidities (NAFLD, etc.) } \\
\text { and can discriminate between the etiology of } \\
\text { pancreatic adenocarcinoma. }\end{array}$ & {$[100]$} \\
\hline
\end{tabular}


Some bacterial species showed a strong association with pancreatic adenocarcinoma. In the oral microbiome, Porphyromonas gingivalis increased in pancreatic adenocarcinoma $[64,82,83,85,101]$. Helicobacter pylori [62,69,70], Enterobacter, Enterococcus [64,90,92,93], Fusobacteria [89,94,102], and E. coli $[64,93]$ were also shown to increase in pancreatic adenocarcinoma patients in multiple studies. In a study assessing intratumor DNA and serum cell-free DNA (1000+ patients), Fusobacteria count in tumors was higher compared to the healthy, untransformed tissues [102]. Fungal species, like Malassezia, also increased in pancreatic adenocarcinoma patients [68]. The oral microbiome can be used for diagnosis [63]. In fact, different risk factors of pancreatic adenocarcinoma are associated with changes to the microbiome, including smoking [103], poor oral health or tooth loss [78], or recurrent pancreatitis. There is a lower bacterial load in pancreatitis than in pancreatic adenocarcinoma.

Pancreatic bacterial invasion predominantly induces persistent inflammation. Both the innate and adaptive immunity participate in recognizing pancreatic bacteria and orchestrating the subsequent inflammatory reaction $[39,40]$. The involvement of Th1, Th2, and Th17 responses have all been demonstrated [41,42]. In pancreatic adenocarcinoma, the proportions of LPS-producing bacteria (e.g., Prevotella, Hallella, and Enterobacter [43]) increase. Lipopolysaccharide (LPS) can bind to the Toll-like (TLR) receptors; TLR2, TLR4, and TLR9 are associated with pancreatic adenocarcinoma development [104]. TLR activation induces the STAT3 and NF- $\mathrm{kB}$ pathways, which act as tumorigenic factors increasing cellular proliferation and suppressing apoptosis [39].

Besides the direct immunogenicity of the microbiome, an endocrine-like function was also described in several cancers [30,105-107] including pancreatic adenocarcinoma. Bacteria can produce bacterial metabolites that enter the systemic circulation and act on distant cancer cells. This process possesses features of endocrine signaling: a chemical entity is synthesized at one location, then transferred to another anatomical site where it binds to receptors and exerts biological responses there. Hereby, we will review the bacterial metabolites with possible pro- or anti-neoplastic features in pancreatic adenocarcinoma.

\section{Bacterial Metabolites Playing Role in Pancreatic Adenocarcinoma}

The gut microbiome harbors a large number of species with an immense and diverse metabolism. Bacterial metabolites or components of bacteria can enter the systemic circulation of the host and be transferred to distant sites where the metabolites can exert hormone-like effects $[19,30,108]$. Bacterial metabolism is largely dysregulated in pancreatic adenocarcinoma [43]. Below, we will review the source and (possible) roles of pro- or anti-carcinogenic bacterial metabolites (Figure 1).

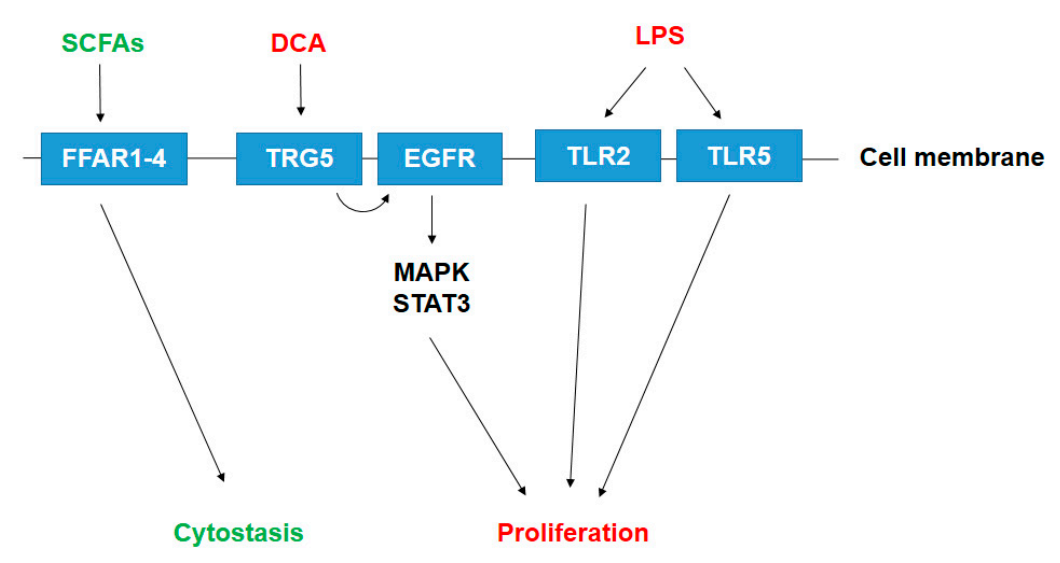

Figure 1. Known bacterial metabolite-elicited signaling pathways in pancreatic adenocarcinoma. Pro-proliferative metabolites are shown in red; antiproliferative metabolites are shown in green. Abbreviations: SCFA-short chain fatty acid, DCA-deoxycholic acid, LPS-lipopolysaccharide, FFAR-free fatty acid receptor, TGR5-Takeda G Protein-Coupled Receptor 5/ G-protein-coupled bile acid receptor, EGFR-Epidermal growth factor receptor, TLR-Toll-like receptor, MAPK-mitogen activated protein kinase, STAT—Signal transducer and activator of transcription. 


\subsection{Short Chain Fatty Acids (SFCA)}

Short chain fatty acids (SCFAs), namely acetate, propionate, butyrate, and lactate, are derived from non-digestible carbohydrates by bacterial saccharolytic fermentation $[109,110]$. The major SCFAs are acetate, propionate, and butyrate [111]. A smaller quantity of SCFA can be formed by amino acid deamination; this is the only source of branched-chain short chain fatty acids [110]. Hydrolysis, glycolysis, and the pentose-phosphate pathways are the key pathways for SCFA production [111], nevertheless, other pathways are also active. SCFAs are produced in the colon. SCFA production affects the $\mathrm{pH}$ of the colon and, hence, modulates the composition of the microbiome in the colon. SCFAs can reduce the proliferation of Enterobacteriaceae (e.g., E. coli, Salmonella ssp., or Clostridia ssp.) and Borrelia burgdorferi [112-115]. Furthermore, SCFAs can modulate the composition of the gut microbiome through the direct modulation of the immune system [116].

SCFA production is common among bacteria. Bacteroidetes primarily produce acetate and propionate, while Firmicutes chiefly produce butyrate [117]. Akkermansia muciniphila has a pivotal role in propionate synthesis through the degradation of mucin [118]. Lachnospiraceae, Ruminococcus obeum, and Roseburia inulinivorans produce propionate through the degradation of deoxy sugars (e.g., fucose, rhamnose), while Bacteroidetes and Negativicutes use hexoses to produce propionate [119]. Other propionate producers are Phascolarctobacterium spp., Dialister spp., Veillonella spp., Salmonella spp., Megasphaera elsdenii, and Coprococcus catus [120,121]. Acetate is predominantly produced by Lactobacillus spp., Bifidobacterium spp., Akkermansia muciniphila, Bacteroides spp., Prevotella spp., Ruminococcus spp., and Streptococcus spp [108]. The bulk of butyrate production can be linked to Odoribacter, Anaeotruncus, Faecalibacterium prausnitzii, Eubacterium rectale, Roseburia faecis, Clostridium leptum, Coprococcus eutactus, Faecalibacterium prausnitzii, Eubacterium rectale, Anaerostipes caccae, Eubacterium hallii, and an unnamed cultured species SS2/1 [120-123]. The bacterial species that produce bacterial metabolites are summarized in Table 2.

Table 2. The microbial source of the metabolites mentioned in the review.

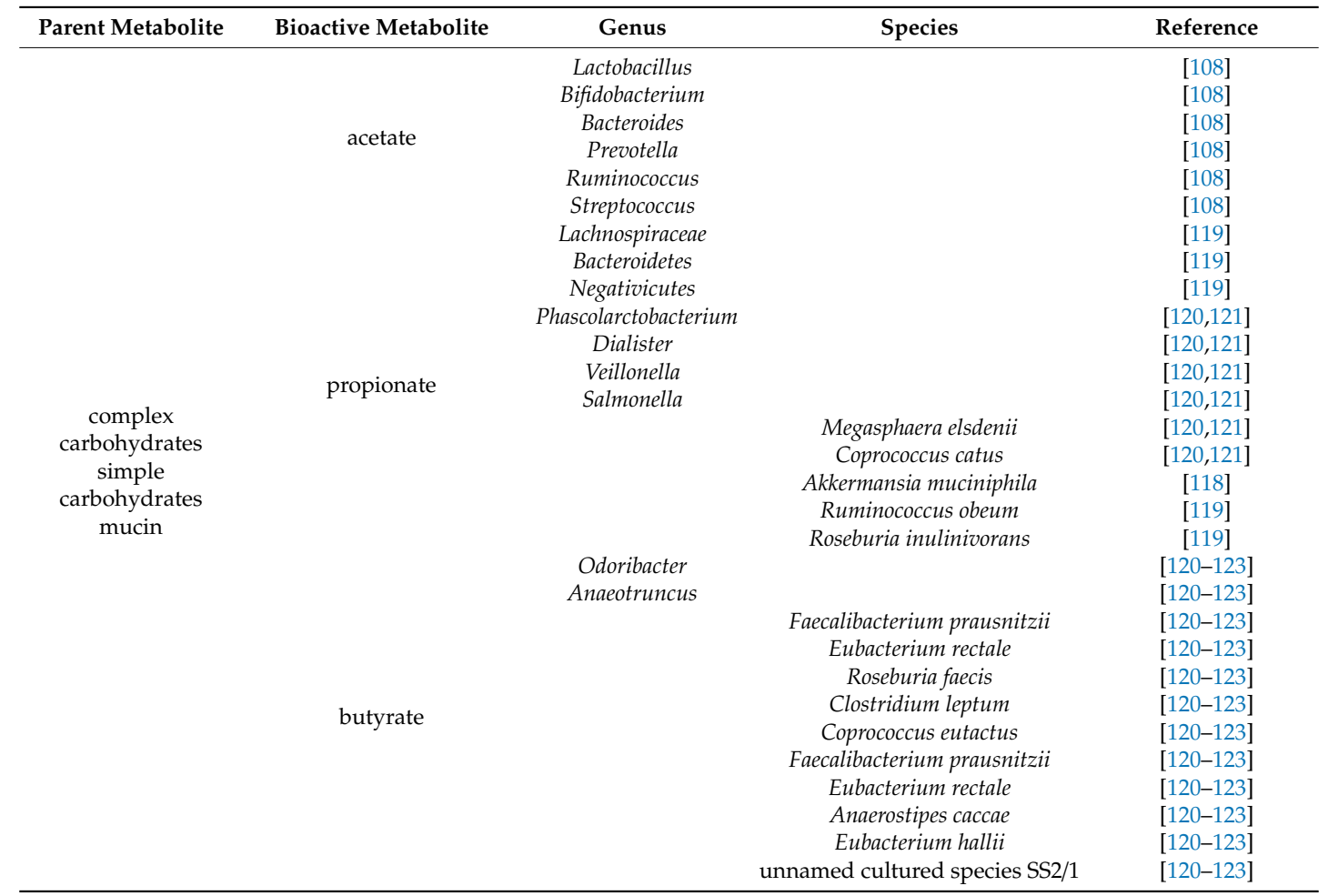


Table 2. Cont.

\begin{tabular}{|c|c|c|c|c|}
\hline Parent Metabolite & Bioactive Metabolite & Genus & Species & Reference \\
\hline \multirow{9}{*}{ primary bile acids } & \multirow{9}{*}{ secondary bile acids } & Clostridium & & [124-129] \\
\hline & & Lactobacillus & & [124-129] \\
\hline & & Bifidobacterium & & [124-129] \\
\hline & & Eubacterium & & {$[124-126,128]$} \\
\hline & & Ruminococcus & & [124-126,128] \\
\hline & & Escherichia & & {$[124-126,128]$} \\
\hline & & & Bacteroides fragilis & [124-129] \\
\hline & & & Bacteroides vulgatus & [124-129] \\
\hline & & & Listeria monocytogenes & [124-129] \\
\hline & \multirow{14}{*}{ polyamines } & & E. coli & {$[108,130,131]$} \\
\hline & & & Enterococcus faecalis & {$[108,130,131]$} \\
\hline & & & Staphylococcus aureus & {$[108,130,131]$} \\
\hline & & & Haemophilus influenzae & {$[108,130,131]$} \\
\hline & & & Neisseria flava & {$[108,130,131]$} \\
\hline & & & Pseudomonas aeruginosa & {$[108,130,131]$} \\
\hline & & & Campylobacter jejuni & {$[108,130,131]$} \\
\hline & & & Yersinia pestis & {$[108,130,131]$} \\
\hline & & & Vibrio cholerae & {$[108,130,131]$} \\
\hline & & & Bacteroides dorei & {$[108,130,131]$} \\
\hline & & & Bacteroides thetaiotaomicron & {$[108,130,131]$} \\
\hline & & & Bacteroides fragilis & {$[108,130,131]$} \\
\hline & & & Bacillus subtilis & {$[108,130,131]$} \\
\hline & & & Proteus mirabilis & {$[108,130,131]$} \\
\hline \multirow{4}{*}{ lysine } & \multirow{4}{*}{ cadaverine } & \multirow[t]{4}{*}{ Streptococcus } & & [132] \\
\hline & & & Shigella flexneri & [132] \\
\hline & & & Shigella sonnei & [132] \\
\hline & & & Escherichia coli & [132] \\
\hline \multirow{5}{*}{ tryptophan } & \multirow{2}{*}{ tryptamine } & & Clostridium sporogenes & [133] \\
\hline & & & Ruminococcus gnavus & [133] \\
\hline & \multirow{3}{*}{ indole acetic acid } & Lactobacillus & & [133] \\
\hline & & Clostridium & & [133] \\
\hline & & Bacteroides & & [133] \\
\hline
\end{tabular}

The human serum reference concentrations of SCFAs fall into the range of 10-100 $\mu \mathrm{M}$ [134-136]. However, local concentrations can be as high as $1 \mathrm{mM}$ [137]. SCFAs primarily bind to the free fatty acid receptors (FFARs) found on both cancer cells and stromal cells $[120,121,138,139]$. SCFAs can be utilized as an energy source by cells [108] and SCFAs can modulate epigenetics through inhibiting histone deacetylases [140-142]. The activation of SCFA receptors controls numerous cancer hallmarks, including cell proliferation, apoptosis, cell invasion, gene expression, metabolism, and immune processes [140-144].

Acetate can ameliorate pancreatitis and its sequels, and, hence, protect against a risk factor of pancreatic adenocarcinoma [145]. Acetate drives the epigenetic reprogramming of mesenchymal stem cells towards cancer-associated fibroblasts that enhance the invasiveness of pancreatic adenocarcinoma cells [146]. Butyrate, at a $2 \mathrm{mM}$ concentration, can reduce the proliferation of cultured pancreatic adenocarcinoma cells (Panc-1 and HPAF cells) and induce differentiation towards a secretory phenotype marked by ultrastructural changes [147]. Furthermore, a hyaluronic acid conjugate of butyrate proved to be cytostatic in a cultured pancreatic adenocarcinoma cell line [148]. Valproic acid, a branched chain synthetic SCFA, was also cytostatic in pancreatic adenocarcinoma cells when given in combination with 5-fluorouracil, suggesting similar properties for bacterial SCFAs [149]. In the pancreatic adenocarcinoma-associated oncobiome, probiotics and butyrate-producing bacteria decreased [43], suggesting that the above-detailed beneficial effects of SCFAs are largely suppressed in the disease.

\subsection{Secondary Bile Acids}

Chenodeoxycholic acid (CDCA) and cholic acid (CA) are primary bile acids, which are mainly synthesized in the liver; however, extrahepatic tissues (e.g., ovaries, macrophages, vascular endothelium, and brain) can contribute to this synthesis [150]. Primary bile acids are conjugated to glycine or taurine and are secreted into the bile, then, via bile, into the duodenum. Hepatic primary bile acids emulsify 
fats and activate lipases. The microbiome of the gut (mostly in the large bowels) dehydroxylate and deconjugate bile acids. Thus, primary bile acids are modified to produce secondary bile acids, including lithocholic acid (LCA), deoxycholic acid (DCA), and ursodeoxycholic acid (UDCA) [151]. There are 16 bile acids in early life, while in adulthood there are 20 different bile acids in humans $[124,152,153]$. The majority of bile acids undergo reuptake via the portal circulation and are then transported to the liver, where secondary bile acids are re-hydroxylated and re-conjugated for reuse. This cycle is called the enterohepatic circulation of bile acids. A small fraction of the reabsorbed bile acids can enter the systemic circulation [154] and systemic bile acids exert hormone-like, systemic effects [23,30,155-157].

The primary-to-secondary bile acid conversion is linked to the gut microbiome. Primarily, colonic bacteria are responsible for bile acid conversion; nevertheless, upper segments of the gastrointestinal tract may also play a role in bile acid transformation. Deconjugation takes place first, followed by oxidation, dehydroxylation, and epimerization. Deconjugation is catalyzed by bile salt hydrolases. Bacteroides fragilis, Bacteroides vulgatus, Listeria monocytogenes, Clostridium, Lactobacillus, and Bifidobacterium possess bile salt hydrolases [124-129]. Oxidation and epimerization activities are linked to intestinal Firmicutes (Clostridium, Eubacterium, and Ruminococcus), Bacteroides, and Escherichia, while dehydroxylation is linked to Clostridia and Eubacteria [124-126,128]. The enzymes involved in secondary bile acid production are assembled in the bile acid inducible (bai) operon in bacteria [151].

Bile acids have multiple receptors, including farnesoid-X-receptor (FXR), liver-X receptor (LXR), Takeda G Protein-Coupled Receptor 5/G-protein-coupled bile acid receptor (TGR5), constitutive androstane receptor (CAR), vitamin D receptor (VDR), and pregnane $X$ receptor (PXR). These receptors are nuclear receptors, except for TGR5. Through these receptors, bile acids impact on immune responses, gastrointestinal mucosal barrier function, gestation [158], carcinogenesis [23,34], and metabolic diseases $[155,159]$.

Bile acid homeostasis is largely hampered in cancer and metabolic diseases [160]. Originally, bile acids were regarded as procarcinogens [161]. However, recent advances suggest that some secondary bile acids can behave as both pro- and anti-carcinogens, depending on the cancer in question and the concentration of the bile acid present $[23,34,105,107,162-169]$. Bile acids also modulate the composition of the microbiome [160,170-176] and facilitate bacterial translocation into tissues [177], a key step in the carcinogenesis of pancreatic adenocarcinoma. Bacteria have different sensitivity for bile acids. Enterococci are considered bile acid resistant bacteria, which may explain the reports showing increased abundance of this bacteria in pancreatic adenocarcinoma [65,90,93].

Bile acid levels were reported to increase in pancreatic adenocarcinoma. A study comprised of 15 patients with pancreatic cancer and 15 patients with benign disease showed increasing trends in all bile acid species detected in pancreatic cancer patients. Increases in unconjugated bile acid levels in pancreatic adenocarcinoma patients were significant and surprisingly large (26 fold) [178].

Most bile acids have a carcinogenic role in pancreatic adenocarcinoma. Bile acids modulate risk factors for pancreatic adenocarcinoma; bile acids impact pancreatitis and bile acid efflux disorders, type II diabetes, obesity, and hyperlipidemia. Furthermore, bile acids reduce susceptibility to apoptosis, induce inflammatory mediators, and may perturb membranes and cellular movement (reviewed in [179]). Gallstones can obstruct the outflow of bile and, hence, can induce and sustain pancreatitis [180], a risk factor for pancreatic adenocarcinoma [179,181,182]. Exposure of pre-malignant pancreas ductal cells to bile may lead to carcinogenic transformation through inflammatory signaling, as demonstrated in rodent and human data [183-186]. DCA, through binding to TGR5, can activate EGFR, mitogen-activated protein kinase, and STAT3 signaling in pancreatic adenocarcinoma cells, inducing cell cycle progression [187]. Interestingly, there seems to be a selectivity among bile acids, as UDCA inhibits the epithelial-to-mesenchymal transition in pancreatic adenocarcinoma cell lines, and in that regard, acts as an anti-carcinogenic factor [188].

Expression levels for VDR [189], FXR [190], and PXR [191] are higher in tumor tissue than in the normal tissue of the pancreas. $\operatorname{LXR} \beta$, but not $\operatorname{LXR} \alpha$, is abundantly expressed in human pancreatic adenocarcinoma cases [192]. In the serum of PDAC patients, components of the LXR/RXR system 
are enriched [193]. Furthermore, higher FXR expression correlates with higher TNM stage, shorter survival, and poorer prognosis [190]. Higher PXR expression correlated with higher histological grade of pancreatic adenocarcinoma [191]. Nevertheless, unexpectedly, enhanced PXR/RXR $\beta$ expression correlated with smaller tumor size and the absence of lymph node metastases and longer survival [191]. Additionally, LXR agonist treatments disrupted proliferation, cell-cycle progression, and colony-formation in PDAC cells [194].

\subsection{Polyamines}

Polyamine metabolism is dysregulated in pancreatic adenocarcinoma [195]. The functional role of polyamine biosynthesis in (human) pancreatic adenocarcinoma is highlighted by the fact that the effects of the standard cytostatic therapies can be accentuated or ameliorated by modulation of the polyamine cycle [196-200]. Cadaverine, putrescine, spermine, and spermidine are classified as polyamines, but bacteria can produce other polyamines also [131,201].

Enzymes of the polyamine pathway had been identified in numerous species. However, the functional characterization of polyamine biosynthesis is limited to a few species [131]. E. coli, Enterococcus faecalis, Staphylococcus aureus, Haemophilus influenzae, Neisseria flava, Pseudomonas aeruginosa, Campylobacter jejuni, Yersinia pestis, Vibrio cholerae, Bacteroides dorei, Bacteroides thetaiotaomicron, Bacteroides fragilis, Bacillus subtilis, and Proteus mirabilis were shown to produce, accumulate, or need/use polyamines $[108,130,131]$.

Cadaverine is a decarboxylation product of lysine and the bacterial enzymes LdcC and CadA are responsible for cadaverine biosynthesis [202,203]. Both the human body and bacteria can produce cadaverine. Shigella flexneri, Shigella sonnei, Escherichia coli, and Streptococcus possess enzymes for cadaverine biosynthesis [132]. Putrescine can be derived from arginine through decarboxylation, as is the case in E. coli [108]. Polyamines support bacterial growth and biofilm formation and in many pathogenic species are considered virulence factors [131].

A metabolomic and metatranscriptomic study of the fecal microbiome from a murine pancreatic adenocarcinoma model [67] showed that bacterial polyamine biosynthetic capacity was upregulated and aggravated by tumor progression. The main polyamines synthesized were putrescine, spermine, and spermidine. In accordance with these results, serum polyamine levels were also higher in pancreatic adenocarcinoma-bearing mice and patients. In contrast, Ren and co-workers [43] found that polyamine biosynthesis and transport pathways were downregulated in samples from pancreatic adenocarcinoma patients. Nevertheless, the lysine and putrescine transport systems were upregulated.

\subsection{Bacterial Lipopolysaccharide (LPS)}

Lipopolysaccharides, lypoglycans, or endotoxins are components of the bacterial outer membrane in Gram-negative bacteria [204,205]. Although LPS is not a classical bacterial metabolite in the strict sense, LPS seems to play a crucial role in the pathogenesis of pancreatic adenocarcinoma. Lipopolysaccharides are built upon a lipid anchor to which a polysaccharide chain is attached. The inherent role of LPS is to protect bacteria against toxins, antibiotics, or bile acids. However, LPS has high immunogenic potential and is considered a member of the pathogen associated molecular patterns (PAMPs). LPS elicits its effects through TLR4 and TLR2 receptors to induce innate immunity [204,205].

In pancreatic adenocarcinoma-associated oncobiosis, the proportion of LPS producing bacteria (Prevotella, Hallella, and Enterobacter) increases [43]. In addition, TLR2, TLR4, and TLR9 [104] and the downstream target of TLR4, MyD88 [40], are associated with pancreatic adenocarcinoma development. Taken together, LPS-induced TLR signaling likely plays a key role in maintaining inflammation in pancreatic adenocarcinoma.

\subsection{Tryptophan Metabolites}

Tryptophan is an amino acid with a very complex and intricate metabolism, in which bacterial metabolism plays a major role. A considerable portion of tryptophan, $4-6 \%$, is metabolized by bacteria 
to yield indol derivatives [206]. In germ-free mice, serum tryptophan levels increase, emphasizing the volume of bacterial tryptophan degradation [133,207-210]. The bacterial metabolism of tryptophan has multiple branches $[133,206]$, described as follows:

(1) The decarboxylation of tryptophan yields tryptamine. Clostridium sporogenes and Ruminococcus gnavus possess enzymes for tryptophan decarboxylation [133].

(2) Tryptophanase deaminates tryptophan to indole pyruvic acid, which is then metabolized to indole. Indole can be further oxidized and the subsequent conjugation of sulphate yields indican. Tryptophanase, denoted as TnaA, can be found in the tryptophanase operon [211]. Tryptophanase expression is widespread among bacteria [212,213].

(3) Indole pyruvic acid can be decarboxylated to indole acetaldehyde. Indole acetaldehyde can be converted to tryptophol or indole acetic acid. Indole acetic acid can be decarboxylated to yield skatole or conjugated with glutamine to yield indole acetic acid-glutamine. The main genera for this pathway are Lactobacillus, Clostridium, and Bacteroides [133].

(4) The reduction of indole pyruvic acid yields indole lactate, the dehydration of which yields indole acrylic acid. This compound can be reduced to indole propionic acid. Indole propionic acid can be further converted by human enzymes.

Tryptophan-derivatives (indoles) are ligands for the aryl hydrocarbon receptor (AHR) and can also bind to the PXR receptor [214-216]. AHR activation is a key element in the regulation of the immune system [133,217]. A tryptophan-poor diet has immunosuppressive effects in an AHR-dependent fashion [218]. By modulating mucosal immunity through AHR, indole derivatives influence the composition of the gut microbiome. For example, indole-derivatives can facilitate the expansion of Lactobacillus reuteri and inhibit the growth of pathogenic bacteria [214,219-221]. Furthermore, Lactobacillus utilizes tryptophan as an energy source [214].

Although direct data are missing for the effects of indole-derivatives in pancreatic adenocarcinoma, the invasive behavior of pancreatic adenocarcinoma cells can be modulated through the selective AHR modulators, Omeprazole and Tranilast [222]. Furthermore, as we noted above, a higher PXR expression correlates with a higher histological grade of pancreatic adenocarcinoma, while enhanced PXR/RXR $\beta$ expression correlates with a smaller tumor size, the absence of lymph node metastases, and longer survival [191].

\subsection{Other Metabolites}

To date, two studies reported in silico reconstruction of metabolic pathways of the microbiome in pancreatic adenocarcinoma. These data identify bacterial metabolites that potentially influence pancreatic adenocarcinoma cells or carcinogenesis itself, thus, we review these data and provide a list in Table 3.

Mendez and colleagues [67] reported a time course experiment using a murine model of pancreatic adenocarcinoma. The results of this experiment revealed that the microbiome in pancreatic adenocarcinoma shifted towards nucleotide, lipid, and polyamine biosynthesis that was accentuated during the progression of the disease. Increased polyamine biosynthesis was confirmed by direct measurement of polyamines in the serum of tumor-bearing mice and healthy controls and pancreatic adenocarcinoma patients. In addition, hexitol fermentation, carbohydrate metabolism, and vitamin biosynthesis and metabolism were upregulated.

The second study was a prospective study of 85 pancreatic adenocarcinoma patients and 57 matched healthy controls in which the fecal microbiome was assessed [43]. A decrease was observed in various transport systems, amino acid metabolism, and core metabolic pathways in pancreatic adenocarcinoma patients. Among the upregulated pathways were genes for amino acid metabolism, carbohydrate metabolism, transport systems, and metabolic pathways. 
Table 3. Bacterial metabolic pathways dysregulated in pancreatic adenocarcinoma.

\begin{tabular}{|c|c|c|c|}
\hline Study & $\begin{array}{l}\text { Direction of Regulation } \\
\text { in Patients }\end{array}$ & Biological Process & Biochemical Process \\
\hline \multirow{6}{*}{ [67] } & \multirow{6}{*}{ upregulated } & & Nucleotide biosynthesis \\
\hline & & & Lipid biosynthesis \\
\hline & & & Polyamine biosynthesis \\
\hline & & & Hexitol fermentation \\
\hline & & & Carbohydrate metabolism \\
\hline & & & Vitamin biosynthesis and metabolism \\
\hline \multirow{38}{*}{ [43] } & \multirow{13}{*}{ downregulated } & \multirow{6}{*}{ transport systems } & Phosphate transport system (M00222) \\
\hline & & & Cobalt transport system (M00245) \\
\hline & & & Mannopine transport system (M00301) \\
\hline & & & Glutamate transport system (M00233) \\
\hline & & & Trehalose-maltose transport system (M00204) \\
\hline & & & Spermidine-putrescine transport system (M00299) \\
\hline & & min & Histidine biosynthesis (M00026) \\
\hline & & amino acid metabolism & Glutamate transport system (M00233) \\
\hline & & & Complex I/NADH dehydrogenase (M00144) \\
\hline & & & Pentose phosphate pathway/non-oxidative phase (M00007) \\
\hline & & metabolic pathways & V type ATPase (M00159) \\
\hline & & & Pyrimidine deoxyribonucleotide biosynthesis (M00053) \\
\hline & & & Pyruvate ferredoxin oxidoreductase (M00310) \\
\hline & \multirow{25}{*}{ upregulated } & \multirow{8}{*}{ amino acid metabolism } & Leucine biosynthesis (M00019) \\
\hline & & & Twin arginine translocation/Tat system (M00336) \\
\hline & & & Histidine degradation (M00045) \\
\hline & & & Methionine salvage pathway (M00034) \\
\hline & & & Lysine arginine ornithine transport system (M00225) \\
\hline & & & Dipeptide transport system (M00324) \\
\hline & & & Arginine transport system (M00229) \\
\hline & & & Histidine transport system (M00226) \\
\hline & & \multirow{2}{*}{$\begin{array}{l}\text { carbohydrate } \\
\text { metabolism }\end{array}$} & Oligogalacturonide transport system (M00202) \\
\hline & & & Entner Doudoroff pathway (M00008) \\
\hline & & \multirow{5}{*}{ transport systems } & Putative spermidine putrescine transport system (M00193) \\
\hline & & & Microcin C transport system (M00349) \\
\hline & & & Putrescine transport system (M00300) \\
\hline & & & Sec secretion system (M00335) \\
\hline & & & Histidine transport system (M00226) \\
\hline & & \multirow{8}{*}{ metabolic pathways } & Pyridoxal biosynthesis (M00124), Citrate cycle (M00011) \\
\hline & & & Complex II/succinate dehydrogenase (M00150) \\
\hline & & & Glyoxylate cycle (M00012) \\
\hline & & & C5 isoprenoid biosynthesis/non-mevalonate pathway (M00096) \\
\hline & & & Ubiquinone biosynthesis (M00117) \\
\hline & & & Prokaryotic GABA biosynthesis (M00136) \\
\hline & & & Lipopolysaccharide biosynthesis (M00060) \\
\hline & & & Bacterial DNA polymerase III complex (M00260) \\
\hline & & \multirow{2}{*}{$\begin{array}{l}\text { polyamine biosynthesis } \\
\text { and transport }\end{array}$} & Polyamine biosynthesis (M00133) \\
\hline & & & Spermidine putrescine transport system (M00299) \\
\hline
\end{tabular}

\section{Supporting Clinical Decision Making, Diagnostic Applications}

As we noted earlier, certain studies assessing the oncobiome in pancreatic adenocarcinoma came to the conclusion that the composition of the oral $[63,82,86,88,223]$, gut [43], pancreatic [102], and fecal [100] microbiomes differ from the corresponding healthy microbiomes. Thus, the microbiomes 
can be used for diagnostic applications. Diagnostics can be useful for the assessment of the risk for tumor development (i.e., tumor detection) [82], survival prediction [41,91], deducting etiology [100], predicting mortality [89], and selecting between the forms of the disease (e.g., obstructive versus non-obstructive forms [43]).

Most studies mentioned above had low patient numbers (tens of patients to a few hundred) and, therefore, did not reach the level of statistical significance. When already existing shotgun sequencing data of tumor DNA was assessed for the presence of bacterial DNA detected statistically [102], counts of bacteria in tumors differed from the corresponding non-transformed tissues. Importantly, patterns were identified that had suitable specificity and selectivity values for subsequent diagnostic applications. Furthermore, these patterns were detectable in serum in the form of cell-free DNA, suggesting that serum could be used for diagnostic applications [102]. In addition, oral swab or feces can be used as easily accessible biomaterials for the detection of pancreatic adenocarcinoma $[82,88,100]$.

As the detection of pancreatic adenocarcinoma is difficult at early (curable) stages, early detection through detecting oncobiotic transformation has clear advantages for patients. The choice of antibiotics used for premedication before surgical excision of pancreatic adenocarcinoma can also be based on the composition of the pancreatic microbiome [92].

\section{Future Directions}

Oncobiosis in pancreatic adenocarcinoma is a complex process, involving multiple microbiome compartments, including the oral, gastric, duodenal, ductal, pancreatic, and fecal compartments. The bacterial colonization of the pancreas drives inflammation and probably facilitates the initiation and progression of the disease to determine the aggressiveness of the disease. Furthermore, there seems to be a large set of bacterial metabolites released into the circulation or tumor microenvironment that has direct effects on the behavior of pancreatic adenocarcinoma cells (Figure 2).

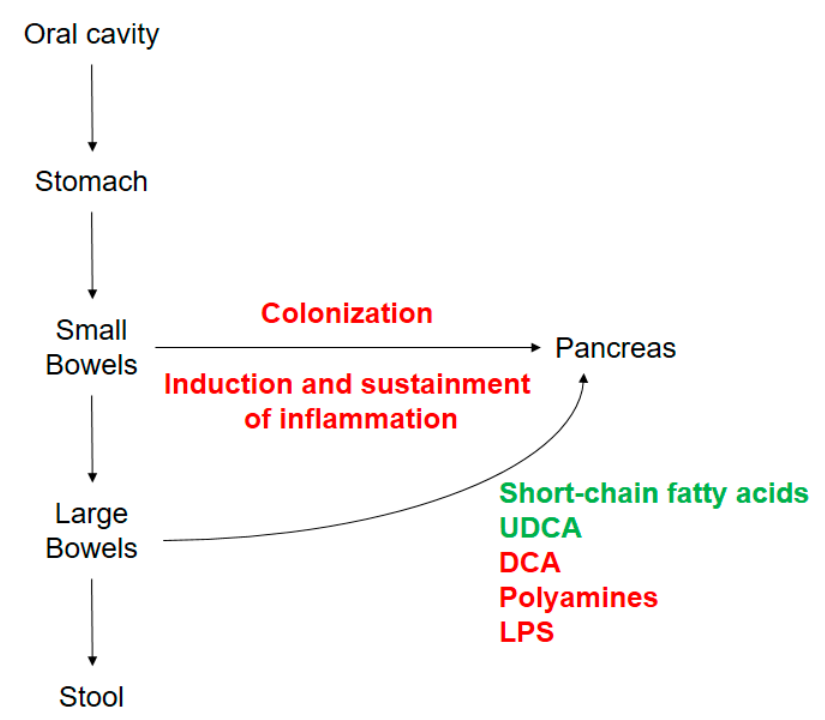

Figure 2. Schematic representation of the role of oncobiosis in pancreatic adenocarcinoma. Rows represent the spillover of the dysbiotic microbiome of the oral cavity, stomach, and bowels to the pancreas and feces. Antineoplastic processes are shown in green and neoplastic processes are shown in red. Abbreviations: UDCA—ursodeoxycholic acid, DCA—deoxycholic acid, LPS—lipopolysaccharide.

The involvement of bacterial metabolites is just coming of age in the microbiome field. In other cancers, the involvement of the microbiome has gained ground quickly and holds promise for new treatment modalities $[224,225]$. Studies on the in silico reconstruction of microbiome metabolism and other circumstantial data suggest large changes to the bacterial metabolome, making it likely that such metabolites will be identified and characterized in the future. It is important to note that in studies with 
bacterial metabolites, metabolites must be used in concentrations corresponding to serum or tissue reference concentrations to avoid the non-physiological effects of supraphysiological concentrations.

Establishing the causative role of oncobiosis in pancreatic adenocarcinoma will facilitate the assessment of how antibiotics, probiotics, or prebiotics may modulate the behavior of the disease in analogy to other diseases and studies [59,60,226-228]. Dietary intervention or special diets can be proposed to patients [229]. Thus, the study of the microbiome may change personalized medicine [100]. A better understanding of the oncobiome in pancreatic adenocarcinoma holds the promise of prolonging survival in pancreatic adenocarcinoma.

Author Contributions: All authors contributed to data collection and the writing of the manuscript. All authors have read and agreed to the published version of the manuscript.

Funding: Hungarian Scientific Research Fund: K123975; Hungarian Scientific Research Fund: PD124110; Hungarian Scientific Research Fund: FK128387; Hungarian Scientific Research Fund: GINOP-2.3.2-15-2016-00006; Hungarian Scientific Research Fund: EFOP-3.6.2-16-2017-0006; Hungarian Scientific Research Fund: K120669; Magyar Tudományos Akadémia: Bolyai fellowship; Hungarian Scientific Research Fund: NKFIH-1150-6/2019; Hungarian Scientific Research Fund: ÚNKP-19-4-DE-79.

Acknowledgments: Our work was supported by grants from the NKFIH (K123975, PD124110, FK128387, GINOP-2.3.2-15-2016-00006, EFOP-3.6.2-16-2017-0006, K120669) and by the Faculty of Medicine at the University of Debrecen. EM was supported by the Bolyai Fellowship from the Hungarian Academy of Sciences. The research was financed by the Higher Education Institutional Excellence Program (NKFIH-1150-6/2019) of the Ministry of Innovation and Technology in Hungary, within the framework of the Biotechnology thematic program of the University of Debrecen. EM is supported by the ÚNKP-19-4-DE-79 New National Excellence Program of the Ministry of Human Capacities.

Conflicts of Interest: The authors declare no conflict of interest.

\section{References}

1. Ducreux, M.; Cuhna, A.S.; Caramella, C.; Hollebecque, A.; Burtin, P.; Goere, D.; Seufferlein, T.; Haustermans, K.; Van Laethem, J.L.; Conroy, T.; et al. Cancer of the pancreas: ESMO Clinical Practice Guidelines for diagnosis, treatment and follow-up. Ann. Oncol. 2015, 26, 56-68. [CrossRef]

2. Rawla, P.; Sunkara, T.; Gaduputi, V. Epidemiology of Pancreatic Cancer: Global Trends, Etiology and Risk Factors. World J. Oncol. 2019, 10, 10-27. [CrossRef]

3. Pei, X.; Song, F.; Wang, Z. Emerging incidence trends and application of curative treatments of pancreatic cancer in the USA. Medicine 2019, 98, e17175. [CrossRef]

4. Rahib, L.; Smith, B.D.; Aizenberg, R.; Rosenzweig, A.B.; Fleshman, J.M.; Matrisian, L.M. Projecting cancer incidence and deaths to 2030: The unexpected burden of thyroid, liver, and pancreas cancers in the United States. Cancer Res. 2014, 74, 2913-2921. [CrossRef]

5. Chun, Y.S.; Pawlik, T.M.; Vauthey, J.N. 8th Edition of the AJCC Cancer Staging Manual: Pancreas and Hepatobiliary Cancers. Ann. Surg. Oncol. 2018, 25, 845-847. [CrossRef] [PubMed]

6. Lowery, M.A.; Kelsen, D.P.; Capanu, M.; Smith, S.C.; Lee, J.W.; Stadler, Z.K.; Moore, M.J.; Kindler, H.L.; Golan, T.; Segal, A.; et al. Phase II trial of veliparib in patients with previously treated BRCA-mutated pancreas ductal adenocarcinoma. Eur. J. Cancer 2018, 89, 19-26. [CrossRef] [PubMed]

7. Silvestris, N.; Longo, V.; Cellini, F.; Reni, M.; Bittoni, A.; Cataldo, I.; Partelli, S.; Falconi, M.; Scarpa, A.; Brunetti, O; et al. Neoadjuvant multimodal treatment of pancreatic ductal adenocarcinoma. Crit. Rev. Oncol. Hematol. 2016, 98, 309-324. [CrossRef] [PubMed]

8. Yeo, T.P. Demographics, epidemiology, and inheritance of pancreatic ductal adenocarcinoma. Semin. Oncol. 2015, 42, 8-18. [CrossRef] [PubMed]

9. Waddell, N.; Pajic, M.; Patch, A.M.; Chang, D.K.; Kassahn, K.S.; Bailey, P.; Johns, A.L.; Miller, D.; Nones, K.; Quek, K.; et al. Whole genomes redefine the mutational landscape of pancreatic cancer. Nature 2015, 518, 495-501. [CrossRef] [PubMed]

10. Hashimoto, D.; Arima, K.; Yokoyama, N.; Chikamoto, A.; Taki, K.; Inoue, R.; Kaida, T.; Higashi, T.; Nitta, H.; Ohmuraya, M.; et al. Heterogeneity of KRAS Mutations in Pancreatic Ductal Adenocarcinoma. Pancreas 2016, 45, 1111-1114. [CrossRef]

11. Schwabe, R.F.; Jobin, C. The microbiome and cancer. Nat. Rev. Cancer 2013, 13, 800-812. [CrossRef] [PubMed] 
12. Flores, R.; Shi, J.; Fuhrman, B.; Xu, X.; Veenstra, T.D.; Gail, M.H.; Gajer, P.; Ravel, J.; Goedert, J.J. Fecal microbial determinants of fecal and systemic estrogens and estrogen metabolites: A cross-sectional study. J. Transl. Med. 2012, 10, 253. [CrossRef] [PubMed]

13. Goedert, J.J.; Jones, G.; Hua, X.; Xu, X.; Yu, G.; Flores, R.; Falk, R.T.; Gail, M.H.; Shi, J.; Ravel, J.; et al. Investigation of the association between the fecal microbiota and breast cancer in postmenopausal women: A population-based case-control pilot study. J. Natl. Cancer Inst. 2015, 107, 147. [CrossRef] [PubMed]

14. Robinson, K.M.; Crabtree, J.; Mattick, J.S.; Anderson, K.E.; Dunning Hotopp, J.C. Distinguishing potential bacteria-tumor associations from contamination in a secondary data analysis of public cancer genome sequence data. Microbiome 2017. [CrossRef] [PubMed]

15. Chen, J.; Pitmon, E.; Wang, K. Microbiome, inflammation and colorectal cancer. Semin. Immunol. 2017, 32, 43-53. [CrossRef] [PubMed]

16. Picardo, S.L.; Coburn, B.; Hansen, A.R. The microbiome and cancer for clinicians. Crit. Rev. Oncol. Hematol. 2019, 141, 1-12. [CrossRef]

17. Saus, E.; Iraola-Guzman, S.; Willis, J.R.; Brunet-Vega, A.; Gabaldon, T. Microbiome and colorectal cancer: Roles in carcinogenesis and clinical potential. Mol. Asp. Med. 2019. [CrossRef]

18. De Martel, C.; Ferlay, J.; Franceschi, S.; Vignat, J.; Bray, F.; Forman, D.; Plummer, M. Global burden of cancers attributable to infections in 2008: A review and synthetic analysis. Lancet Oncol. 2012, 13, 607-615. [CrossRef]

19. Miko, E.; Vida, A.; Bai, P. Translational aspects of the microbiome-to be exploited. Cell Biol. Toxicol. 2016, 32, 153-156. [CrossRef]

20. Hall, A.; Versalovic, J. Microbial Metabolism in the Mammalian Gut: Molecular Mechanisms and Clinical Implications. J. Pediatr. Gastroenterol. Nutr. 2018, 66, S72-S79. [CrossRef]

21. Zitvogel, L.; Ayyoub, M.; Routy, B.; Kroemer, G. Microbiome and Anticancer Immunosurveillance. Cell 2016, 165, 276-287. [CrossRef] [PubMed]

22. Kovács, T.; Mikó, E.; Vida, A.; Sebő, É.; Toth, J.; Csonka, T.; Boratkó, A.; Ujlaki, G.; Lente, G.; Kovács, P.; et al. Cadaverine, a metabolite of the microbiome, reduces breast cancer aggressiveness through trace amino acid receptors. Sci. Rep. 2019, 9, 1300. [CrossRef] [PubMed]

23. Miko, E.; Vida, A.; Kovacs, T.; Ujlaki, G.; Trencsenyi, G.; Marton, J.; Sari, Z.; Kovacs, P.; Boratko, A.; Hujber, Z.; et al. Lithocholic acid, a bacterial metabolite reduces breast cancer cell proliferation and aggressiveness. Biochim. Biophys. Acta 2018, 1859, 958-974. [CrossRef] [PubMed]

24. Buchta Rosean, C.; Bostic, R.R.; Ferey, J.C.M.; Feng, T.Y.; Azar, F.N.; Tung, K.S.; Dozmorov, M.G.; Smirnova, E.; Bos, P.D.; Rutkowski, M.R. Preexisting Commensal Dysbiosis Is a Host-Intrinsic Regulator of Tissue Inflammation and Tumor Cell Dissemination in Hormone Receptor-Positive Breast Cancer. Cancer Res. 2019, 79, 3662-3675. [CrossRef]

25. Ingman, W.V. The Gut Microbiome: A New Player in Breast Cancer Metastasis. Cancer Res. 2019, 79, 3539-3541. [CrossRef]

26. Viaud, S.; Daillere, R.; Boneca, I.G.; Lepage, P.; Pittet, M.J.; Ghiringhelli, F.; Trinchieri, G.; Goldszmid, R.; Zitvogel, L. Harnessing the intestinal microbiome for optimal therapeutic immunomodulation. Cancer Res. 2014, 74, 4217-4221. [CrossRef]

27. Routy, B.; Le Chatelier, E.; Derosa, L.; Duong, C.P.M.; Alou, M.T.; Daillere, R.; Fluckiger, A.; Messaoudene, M.; Rauber, C.; Roberti, M.P.; et al. Gut microbiome influences efficacy of PD-1-based immunotherapy against epithelial tumors. Science 2018, 359, 91-97. [CrossRef]

28. Elkrief, A.; Derosa, L.; Kroemer, G.; Zitvogel, L.; Routy, B. The negative impact of antibiotics on outcomes in cancer patients treated with immunotherapy: A new independent prognostic factor? Ann. Oncol. 2019, 30, 1572-1579. [CrossRef]

29. Kovacs, T.; Miko, E.; Ujlaki, G.; Sari, Z.; Bai, P. The Microbiome as a Component of the Tumor Microenvironment. Adv. Exp. Med. Biol. 2020, 1225, 137-153.

30. Miko, E.; Kovacs, T.; Sebo, E.; Toth, J.; Csonka, T.; Ujlaki, G.; Sipos, A.; Szabo, J.; Mehes, G.; Bai, P. Microbiome-Microbial Metabolome-Cancer Cell Interactions in Breast Cancer-Familiar, but Unexplored. Cells 2019, 8, 293. [CrossRef]

31. Hanahan, D.; Weinberg, R.A. Hallmarks of cancer: The next generation. Cell 2011, 144, 646-674. [CrossRef] [PubMed]

32. Hanahan, D.; Weinberg, R.A. The hallmarks of cancer. Cell 2000, 100, 57-70. [CrossRef] 
33. Zitvogel, L.; Daillere, R.; Roberti, M.P.; Routy, B.; Kroemer, G. Anticancer effects of the microbiome and its products. Nat. Rev. Microbiol. 2017, 15, 465-478. [CrossRef] [PubMed]

34. Kovács, P.; Csonka, T.; Kovács, T.; Sári, Z.; Ujlaki, G.; Sipos, A.; Karányi, Z.; Szeőcs, D.; Hegedûs, C.; Uray, K.; et al. Lithocholic acid, a metabolite of the microbiome, increases oxidative stress in breast cancer. Cancers 2019, 11, 1255. [CrossRef] [PubMed]

35. Vergara, D.; Simeone, P.; Damato, M.; Maffia, M.; Lanuti, P.; Trerotola, M. The Cancer Microbiota: EMT and Inflammation as Shared Molecular Mechanisms Associated with Plasticity and Progression. J. Oncol. 2019. [CrossRef] [PubMed]

36. Lau, A.; Villeneuve, N.F.; Sun, Z.; Wong, P.K.; Zhang, D.D. Dual roles of Nrf2 in cancer. Pharmacol. Res. 2008, 58, 262-270. [CrossRef] [PubMed]

37. Jezierska-Drutel, A.; Rosenzweig, S.A.; Neumann, C.A. Role of oxidative stress and the microenvironment in breast cancer development and progression. Adv. Cancer Res. 2013, 119, 107-125.

38. Smolková, K.; Mikó, E.; Kovács, T.; Leguina-Ruzzi, A.; Sipos, A.; Bai, P. NRF2 in regulating cancer metabolism. Antioxid. Redox Signal. 2020. [CrossRef]

39. Pagliari, D.; Saviano, A.; Newton, E.E.; Serricchio, M.L.; Dal Lago, A.A.; Gasbarrini, A.; Cianci, R. Gut Microbiota-Immune System Crosstalk and Pancreatic Disorders. Mediators Inflamm. 2018, 2018, 7946431. [CrossRef]

40. Ochi, A.; Nguyen, A.H.; Bedrosian, A.S.; Mushlin, H.M.; Zarbakhsh, S.; Barilla, R.; Zambirinis, C.P.; Fallon, N.C.; Rehman, A.; Pylayeva-Gupta, Y.; et al. MyD88 inhibition amplifies dendritic cell capacity to promote pancreatic carcinogenesis via Th2 cells. J. Exp. Med. 2012, 209, 1671-1687. [CrossRef]

41. Pushalkar, S.; Hundeyin, M.; Daley, D.; Zambirinis, C.P.; Kurz, E.; Mishra, A.; Mohan, N.; Aykut, B.; Usyk, M.; Torres, L.E.; et al. The Pancreatic Cancer Microbiome Promotes Oncogenesis by Induction of Innate and Adaptive Immune Suppression. Cancer Discov. 2018, 8, 403-416. [CrossRef] [PubMed]

42. Sethi, V.; Kurtom, S.; Tarique, M.; Lavania, S.; Malchiodi, Z.; Hellmund, L.; Zhang, L.; Sharma, U.; Giri, B.; Garg, B.; et al. Gut Microbiota Promotes Tumor Growth in Mice by Modulating Immune Response. Gastroenterology 2018, 155, 33-37. [CrossRef] [PubMed]

43. Ren, Z.; Jiang, J.; Xie, H.; Li, A.; Lu, H.; Xu, S.; Zhou, L.; Zhang, H.; Cui, G.; Chen, X.; et al. Gut microbial profile analysis by MiSeq sequencing of pancreatic carcinoma patients in China. Oncotarget 2017, 8, 95176-95191. [CrossRef] [PubMed]

44. Gopalakrishnan, V.; Spencer, C.N.; Nezi, L.; Reuben, A.; Andrews, M.C.; Karpinets, T.V.; Prieto, P.A.; Vicente, D.; Hoffman, K.; Wei, S.C.; et al. Gut microbiome modulates response to anti-PD-1 immunotherapy in melanoma patients. Science 2018, 359, 97-103. [CrossRef] [PubMed]

45. Buchta Rosean, C.; Feng, T.Y.; Azar, F.N.; Rutkowski, M.R. Impact of the microbiome on cancer progression and response to anti-cancer therapies. Adv. Cancer Res. 2019, 143, 255-294. [CrossRef] [PubMed]

46. Valastyan, S.; Weinberg, R.A. Tumor metastasis: Molecular insights and evolving paradigms. Cell 2011, 147, 275-292. [CrossRef] [PubMed]

47. Kalluri, R.; Weinberg, R.A. The basics of epithelial-mesenchymal transition. J. Clin. Investig. 2009, 119, 1420-1428. [CrossRef]

48. Mani, S.A.; Guo, W.; Liao, M.J.; Eaton, E.N.; Ayyanan, A.; Zhou, A.Y.; Brooks, M.; Reinhard, F.; Zhang, C.C.; Shipitsin, M.; et al. The epithelial-mesenchymal transition generates cells with properties of stem cells. Cell 2008, 133, 704-715. [CrossRef]

49. Biedermann, L.; Zeitz, J.; Mwinyi, J.; Sutter-Minder, E.; Rehman, A.; Ott, S.J.; Steurer-Stey, C.; Frei, A.; Frei, P.; Scharl, M.; et al. Smoking cessation induces profound changes in the composition of the intestinal microbiota in humans. PLOS ONE 2013, 8, e59260. [CrossRef]

50. Schulz, M.D.; Atay, C.; Heringer, J.; Romrig, F.K.; Schwitalla, S.; Aydin, B.; Ziegler, P.K.; Varga, J.; Reindl, W.; Pommerenke, C.; et al. High-fat-diet-mediated dysbiosis promotes intestinal carcinogenesis independently of obesity. Nature 2014, 514, 508-512. [CrossRef]

51. Zarrinpar, A.; Chaix, A.; Panda, S. Daily Eating Patterns and Their Impact on Health and Disease. Trends Endocrinol. Metab. 2016, 27, 69-83. [CrossRef] [PubMed]

52. Zarrinpar, A.; Chaix, A.; Yooseph, S.; Panda, S. Diet and feeding pattern affect the diurnal dynamics of the gut microbiome. Cell Metab. 2014, 20, 1006-1017. [CrossRef]

53. Paschos, G.K.; FitzGerald, G.A. Circadian Clocks and Metabolism: Implications for Microbiome and Aging. Trends Genet. 2017, 33, 760-769. [CrossRef] [PubMed] 
54. Zhang, H.; Cherian, R.; Jin, K. Systemic milieu and age-related deterioration. Geroscience 2019, 41, $275-284$. [CrossRef] [PubMed]

55. Saffrey, M.J. Aging of the mammalian gastrointestinal tract: A complex organ system. Age 2014, 36, 9603. [CrossRef]

56. Singh, H.; Torralba, M.G.; Moncera, K.J.; DiLello, L.; Petrini, J.; Nelson, K.E.; Pieper, R. Gastro-intestinal and oral microbiome signatures associated with healthy aging. Geroscience 2019. [CrossRef]

57. Devaraj, S.; Hemarajata, P.; Versalovic, J. The human gut microbiome and body metabolism: Implications for obesity and diabetes. Clin. Chem. 2013, 59, 617-628. [CrossRef]

58. Ticinesi, A.; Lauretani, F.; Tana, C.; Nouvenne, A.; Ridolo, E.; Meschi, T. Exercise and immune system as modulators of intestinal microbiome: Implications for the gut-muscle axis hypothesis. Exerc. Immunol. Rev. 2019, 25, 84-95.

59. Friedman, G.D.; Oestreicher, N.; Chan, J.; Quesenberry, C.P., Jr.; Udaltsova, N.; Habel, L.A. Antibiotics and risk of breast cancer: Up to 9 years of follow-up of 2.1 million women. Cancer Epidemiol. Biomark. Prev. 2006, 15, 2102-2106. [CrossRef]

60. Mendoza, L. Potential effect of probiotics in the treatment of breast cancer. Oncol. Rev. 2019, $13,422$. [CrossRef]

61. Ranjbar, S.; Seyednejad, S.A.; Azimi, H.; Rezaeizadeh, H.; Rahimi, R. Emerging Roles of Probiotics in Prevention and Treatment of Breast Cancer: A Comprehensive Review of Their Therapeutic Potential. Nutr. Cancer 2019, 71, 1-12. [CrossRef]

62. Lindkvist, B.; Johansen, D.; Borgstrom, A.; Manjer, J. A prospective study of Helicobacter pylori in relation to the risk for pancreatic cancer. BMC Cancer 2008. [CrossRef] [PubMed]

63. Farrell, J.J.; Zhang, L.; Zhou, H.; Chia, D.; Elashoff, D.; Akin, D.; Paster, B.J.; Joshipura, K.; Wong, D.T. Variations of oral microbiota are associated with pancreatic diseases including pancreatic cancer. Gut 2012, 61, 582-588. [CrossRef] [PubMed]

64. Mei, Q.X.; Huang, C.L.; Luo, S.Z.; Zhang, X.M.; Zeng, Y.; Lu, Y.Y. Characterization of the duodenal bacterial microbiota in patients with pancreatic head cancer vs. healthy controls. Pancreatology 2018, 18, 438-445. [CrossRef] [PubMed]

65. Thomas, R.M.; Gharaibeh, R.Z.; Gauthier, J.; Beveridge, M.; Pope, J.L.; Guijarro, M.V.; Yu, Q.; He, Z.; Ohland, C.; Newsome, R.; et al. Intestinal microbiota enhances pancreatic carcinogenesis in preclinical models. Carcinogenesis 2018, 39, 1068-1078. [CrossRef]

66. Archibugi, L.; Signoretti, M.; Capurso, G. The Microbiome and Pancreatic Cancer: An Evidence-based Association? J. Clin. Gastroenterol. 2018, 52, S82-S85. [CrossRef]

67. Mendez, R.; Kesh, K.; Arora, N.; Di Martino, L.; McAllister, F.; Merchant, N.; Banerjee, S.; Banerjee, S. Microbial dysbiosis and polyamine metabolism as predictive markers for early detection of pancreatic cancer. Carcinogenesis 2019, 1. [CrossRef]

68. Aykut, B.; Pushalkar, S.; Chen, R.; Li, Q.; Abengozar, R.; Kim, J.I.; Shadaloey, S.A.; Wu, D.; Preiss, P.; Verma, N.; et al. The fungal mycobiome promotes pancreatic oncogenesis via activation of MBL. Nature 2019, 574, 264-267. [CrossRef]

69. Frulloni, L.; Lunardi, C.; Simone, R.; Dolcino, M.; Scattolini, C.; Falconi, M.; Benini, L.; Vantini, I.; Corrocher, R.; Puccetti, A. Identification of a novel antibody associated with autoimmune pancreatitis. N. Engl. J. Med. 2009, 361, 2135-2142. [CrossRef]

70. Risch, H.A.; Lu, L.; Kidd, M.S.; Wang, J.; Zhang, W.; Ni, Q.; Gao, Y.T.; Yu, H. Helicobacter pylori seropositivities and risk of pancreatic carcinoma. Cancer Epidemiol. Biomark. Prev. 2014, 23, 172-178. [CrossRef]

71. Wang, Y.; Zhang, F.C.; Wang, Y.J. Helicobacter pylori and pancreatic cancer risk: A meta- analysis based on 2049 cases and 2861 controls. Asian Pac. J. Cancer Prev. 2014, 15, 4449-4454. [CrossRef] [PubMed]

72. Rabelo-Goncalves, E.M.; Roesler, B.M.; Zeitune, J.M. Extragastric manifestations of Helicobacter pylori infection: Possible role of bacterium in liver and pancreas diseases. World J. Hepatol. 2015, 7, 2968-2979. [CrossRef] [PubMed]

73. Chen, X.Z.; Wang, R.; Chen, H.N.; Hu, J.K. Cytotoxin-Associated Gene A-Negative Strains of Helicobacter pylori as a Potential Risk Factor of Pancreatic Cancer: A Meta-Analysis Based on Nested Case-Control Studies. Pancreas 2015, 44, 1340-1344. [CrossRef] [PubMed]

74. Maisonneuve, P.; Lowenfels, A.B. Risk factors for pancreatic cancer: A summary review of meta-analytical studies. Int. J. Epidemiol. 2015, 44, 186-198. [CrossRef] [PubMed] 
75. Ertz-Archambault, N.; Keim, P.; Von Hoff, D. Microbiome and pancreatic cancer: A comprehensive topic review of literature. World J. Gastroenterol. 2017, 23, 1899-1908. [CrossRef] [PubMed]

76. Tenti, P.; Aguzzi, A.; Riva, C.; Usellini, L.; Zappatore, R.; Bara, J.; Samloff, I.M.; Solcia, E. Ovarian mucinous tumors frequently express markers of gastric, intestinal, and pancreatobiliary epithelial cells. Cancer 1992, 69, 2131-2142. [CrossRef]

77. Ogrendik, M. Periodontal Pathogens in the Etiology of Pancreatic Cancer. Gastrointest. Tumors. 2017, 3 , 125-127. [CrossRef]

78. Wei, M.Y.; Shi, S.; Liang, C.; Meng, Q.C.; Hua, J.; Zhang, Y.Y.; Liu, J.; Zhang, B.; Xu, J.; Yu, X.J. The microbiota and microbiome in pancreatic cancer: More influential than expected. Mol. Cancer 2019, 18, 97. [CrossRef]

79. Zambirinis, C.P.; Pushalkar, S.; Saxena, D.; Miller, G. Pancreatic cancer, inflammation, and microbiome. Cancer J. 2014, 20, 195-202. [CrossRef]

80. Mima, K.; Nakagawa, S.; Sawayama, H.; Ishimoto, T.; Imai, K.; Iwatsuki, M.; Hashimoto, D.; Baba, Y.; Yamashita, Y.I.; Yoshida, N.; et al. The microbiome and hepatobiliary-pancreatic cancers. Cancer Lett. 2017, 402, 9-15. [CrossRef]

81. Hujoel, P.P.; Drangsholt, M.; Spiekerman, C.; Weiss, N.S. An exploration of the periodontitis-cancer association. Ann. Epidemiol. 2003, 13, 312-316. [CrossRef]

82. Michaud, D.S.; Izard, J.; Wilhelm-Benartzi, C.S.; You, D.H.; Grote, V.A.; Tjonneland, A.; Dahm, C.C.; Overvad, K.; Jenab, M.; Fedirko, V.; et al. Plasma antibodies to oral bacteria and risk of pancreatic cancer in a large European prospective cohort study. Gut 2013, 62, 1764-1770. [CrossRef] [PubMed]

83. Torres, P.J.; Fletcher, E.M.; Gibbons, S.M.; Bouvet, M.; Doran, K.S.; Kelley, S.T. Characterization of the salivary microbiome in patients with pancreatic cancer. PeerJ 2015, 3, e1373. [CrossRef]

84. Nieminen, M.T.; Listyarifah, D.; Hagstrom, J.; Haglund, C.; Grenier, D.; Nordstrom, D.; Uitto, V.J.; Hernandez, M.; Yucel-Lindberg, T.; Tervahartiala, T.; et al. Treponema denticola chymotrypsin-like proteinase may contribute to orodigestive carcinogenesis through immunomodulation. Br. J. Cancer 2018, 118, 428-434. [CrossRef] [PubMed]

85. Fan, X.; Alekseyenko, A.V.; Wu, J.; Peters, B.A.; Jacobs, E.J.; Gapstur, S.M.; Purdue, M.P.; Abnet, C.C.; Stolzenberg-Solomon, R.; Miller, G.; et al. Human oral microbiome and prospective risk for pancreatic cancer: A population-based nested case-control study. Gut 2018, 67, 120-127. [CrossRef] [PubMed]

86. Lu, H.; Ren, Z.; Li, A.; Li, J.; Xu, S.; Zhang, H.; Jiang, J.; Yang, J.; Luo, Q.; Zhou, K.; et al. Tongue coating microbiome data distinguish patients with pancreatic head cancer from healthy controls. J. Oral Microbiol. 2019, 11, 1563409. [CrossRef]

87. Gaiser, R.A.; Halimi, A.; Alkharaan, H.; Lu, L.; Davanian, H.; Healy, K.; Hugerth, L.W.; Ateeb, Z.; Valente, R.; Fernandez Moro, C.; et al. Enrichment of oral microbiota in early cystic precursors to invasive pancreatic cancer. Gut 2019, 68, 2186-2194. [CrossRef]

88. Vogtmann, E.; Han, Y.; Caporaso, J.G.; Bokulich, N.; Mohamadkhani, A.; Moayyedkazemi, A.; Hua, X.; Kamangar, F.; Wan, Y.; Suman, S.; et al. Oral microbial community composition is associated with pancreatic cancer: A case-control study in Iran. Cancer Med. 2020, 9, 797-806. [CrossRef]

89. Mitsuhashi, K.; Nosho, K.; Sukawa, Y.; Matsunaga, Y.; Ito, M.; Kurihara, H.; Kanno, S.; Igarashi, H.; Naito, T.; Adachi, Y.; et al. Association of Fusobacterium species in pancreatic cancer tissues with molecular features and prognosis. Oncotarget 2015, 6, 7209-7220. [CrossRef]

90. Maekawa, T.; Fukaya, R.; Takamatsu, S.; Itoyama, S.; Fukuoka, T.; Yamada, M.; Hata, T.; Nagaoka, S.; Kawamoto, K.; Eguchi, H.; et al. Possible involvement of Enterococcus infection in the pathogenesis of chronic pancreatitis and cancer. Biochem. Biophys. Res. Commun. 2018, 506, 962-969. [CrossRef]

91. Riquelme, E.; Zhang, Y.; Zhang, L.; Montiel, M.; Zoltan, M.; Dong, W.; Quesada, P.; Sahin, I.; Chandra, V.; San Lucas, A.; et al. Tumor Microbiome Diversity and Composition Influence Pancreatic Cancer Outcomes. Cell 2019, 178, 795-806. [CrossRef] [PubMed]

92. Swan, C.D.; Nahm, C.; Samra, J.S.; Mittal, A.; Figtree, M. Microbiology of pancreatoduodenectomy and recommendations for antimicrobial prophylaxis. ANZ J. Surg. 2019, 19, 15560. [CrossRef] [PubMed]

93. Di Carlo, P.; Serra, N.; D’Arpa, F.; Agrusa, A.; Gulotta, G.; Fasciana, T.; Rodolico, V.; Giammanco, A.; Sergi, C. The microbiota of the bilio-pancreatic system: A cohort, STROBE-compliant study. Infect. Drug Resist. 2019, 12, 1513-1527. [CrossRef] [PubMed] 
94. Del Castillo, E.; Meier, R.; Chung, M.; Koestler, D.C.; Chen, T.; Paster, B.J.; Charpentier, K.P.; Kelsey, K.T.; Izard, J.; Michaud, D.S. The Microbiomes of Pancreatic and Duodenum Tissue Overlap and Are Highly Subject Specific but Differ between Pancreatic Cancer and Noncancer Subjects. Cancer Epidemiol. Biomark. Prev. 2019, 28, 370-383. [CrossRef] [PubMed]

95. Boursi, B.; Mamtani, R.; Haynes, K.; Yang, Y.X. Recurrent antibiotic exposure may promote cancer formation-Another step in understanding the role of the human microbiota? Eur. J. Cancer 2015, 51, 2655-2664. [CrossRef]

96. Tsuji, Y.; Watanabe, T.; Kudo, M.; Arai, H.; Strober, W.; Chiba, T. Sensing of commensal organisms by the intracellular sensor NOD1 mediates experimental pancreatitis. Immunity 2012, 37, 326-338. [CrossRef] [PubMed]

97. Leal-Lopes, C.; Velloso, F.J.; Campopiano, J.C.; Sogayar, M.C.; Correa, R.G. Roles of Commensal Microbiota in Pancreas Homeostasis and Pancreatic Pathologies. J. Diabetes Res. 2015, 2015, 284680. [CrossRef]

98. Metagenomics. Alpha and Beta Diversity. Available online: http://www.metagenomics.wiki/pdf/definition/ alpha-beta-diversity (accessed on 20 April 2020).

99. Vida, A.; Bodrogi, B.L.; Balogh, B.; Bai, P. Taxamat: Automated biodiversity data management tool Implications for microbiome studies. Physiol. Int. 2020. [CrossRef]

100. Half, E.; Keren, N.; Reshef, L.; Dorfman, T.; Lachter, I.; Kluger, Y.; Reshef, N.; Knobler, H.; Maor, Y.; Stein, A.; et al. Fecal microbiome signatures of pancreatic cancer patients. Sci. Rep. 2019, 9, 16801. [CrossRef]

101. Michaud, D.S. Role of bacterial infections in pancreatic cancer. Carcinogenesis 2013, 34, 2193-2197. [CrossRef]

102. Poore, G.D.; Kopylova, E.; Zhu, Q.; Carpenter, C.; Fraraccio, S.; Wandro, S.; Kosciolek, T.; Janssen, S.; Metcalf, J.; Song, S.J.; et al. Microbiome analyses of blood and tissues suggest cancer diagnostic approach. Nature 2020, 579, 567-574. [CrossRef] [PubMed]

103. Hujoel, P.P.; Drangsholt, M.; Spiekerman, C.; DeRouen, T.A. Periodontitis-systemic disease associations in the presence of smoking-causal or coincidental? Periodontol 2002, 30, 51-60. [CrossRef] [PubMed]

104. Grimmig, T.; Moench, R.; Kreckel, J.; Haack, S.; Rueckert, F.; Rehder, R.; Tripathi, S.; Ribas, C.; Chandraker, A.; Germer, C.T.; et al. Toll Like Receptor 2, 4, and 9 Signaling Promotes Autoregulative Tumor Cell Growth and VEGF/PDGF Expression in Human Pancreatic Cancer. Int. J. Mol. Sci. 2016, 17, 2060. [CrossRef] [PubMed]

105. Yoshimoto, S.; Loo, T.M.; Atarashi, K.; Kanda, H.; Sato, S.; Oyadomari, S.; Iwakura, Y.; Oshima, K.; Morita, H.; Hattori, M.; et al. Obesity-induced gut microbial metabolite promotes liver cancer through senescence secretome. Nature 2013, 499, 97-101. [CrossRef]

106. Ridlon, J.M.; Bajaj, J.S. The human gut sterolbiome: Bile acid-microbiome endocrine aspects and therapeutics. Acta Pharm. Sin. B 2015, 5, 99-105. [CrossRef]

107. Zeng, H.; Umar, S.; Rust, B.; Lazarova, D.; Bordonaro, M. Secondary Bile Acids and Short Chain Fatty Acids in the Colon: A Focus on Colonic Microbiome, Cell Proliferation, Inflammation, and Cancer. Int. J. Mol. Sci. 2019, 20, 1214. [CrossRef]

108. Sittipo, P.; Shim, J.W.; Lee, Y.K. Microbial Metabolites Determine Host Health and the Status of Some Diseases. Int. J. Mol. Sci. 2019, 20, 5296. [CrossRef]

109. Tan, J.; McKenzie, C.; Potamitis, M.; Thorburn, A.N.; Mackay, C.R.; Macia, L. The role of short-chain Fatty acids in health and disease. Adv. Immunol. 2014, 121, 91-119.

110. Morrison, D.J.; Preston, T. Formation of short chain fatty acids by the gut microbiota and their impact on human metabolism. Gut Microbes. 2016, 7, 189-200. [CrossRef]

111. Den Besten, G.; van Eunen, K.; Groen, A.K.; Venema, K.; Reijngoud, D.J.; Bakker, B.M. The role of short-chain fatty acids in the interplay between diet, gut microbiota, and host energy metabolism. J. Lipid. Res. 2013, 54, 2325-2340. [CrossRef]

112. Lin, Y.H.; Chen, Y.; Smith, T.C., II; Karna, S.L.R.; Seshu, J. Short-Chain Fatty Acids Alter Metabolic and Virulence Attributes of Borrelia burgdorferi. Infect. Immun. 2018, 86. [CrossRef] [PubMed]

113. Cherrington, C.A.; Hinton, M.; Pearson, G.R.; Chopra, I. Short-chain organic acids at ph 5.0 kill Escherichia coli and Salmonella spp. without causing membrane perturbation. J. Appl. Bacteriol. 1991, 70, 161-165. [CrossRef] [PubMed]

114. Duncan, S.H.; Louis, P.; Thomson, J.M.; Flint, H.J. The role of $\mathrm{pH}$ in determining the species composition of the human colonic microbiota. Environ. Microbiol. 2009, 11, 2112-2122. [CrossRef] [PubMed]

115. Prohaszka, L.; Jayarao, B.M.; Fabian, A.; Kovacs, S. The role of intestinal volatile fatty acids in the Salmonella shedding of pigs. Zentralbl. Veterinarmed. B 1990, 37, 570-574. [CrossRef] [PubMed] 
116. Fachi, J.L.; Secca, C.; Rodrigues, P.B.; Mato, F.C.P.; Di Luccia, B.; Felipe, J.S.; Pral, L.P.; Rungue, M.; Rocha, V.M.; Sato, F.T.; et al. Acetate coordinates neutrophil and ILC3 responses against C. difficile through FFAR2. J. Exp. Med. 2020, 217, 133544. [CrossRef]

117. Levy, M.; Thaiss, C.A.; Elinav, E. Metabolites: Messengers between the microbiota and the immune system. Genes Dev. 2016, 30, 1589-1597. [CrossRef]

118. Derrien, M.; Vaughan, E.E.; Plugge, C.M.; de Vos, W.M. Akkermansia muciniphila gen. nov., sp. nov., a human intestinal mucin-degrading bacterium. Int. J. Syst. Evol. Microbiol. 2004, 54, 1469-1476. [CrossRef]

119. Reichardt, N.; Duncan, S.H.; Young, P.; Belenguer, A.; McWilliam Leitch, C.; Scott, K.P.; Flint, H.J.; Louis, P. Phylogenetic distribution of three pathways for propionate production within the human gut microbiota. ISME J. 2014, 8, 1323-1335. [CrossRef]

120. Fernández, J.; Redondo-Blanco, S.; Gutiérrez-del-Río, I.; Miguélez, E.M.; Villar, C.J.; Lombó, F. Colon microbiota fermentation of dietary prebiotics towards short-chain fatty acids and their roles as anti-inflammatory and antitumour agents: A review. J. Funct. Foods 2016, 25, 511-522. [CrossRef]

121. Koh, A.; De Vadder, F.; Kovatcheva-Datchary, P.; Backhed, F. From Dietary Fiber to Host Physiology: Short-Chain Fatty Acids as Key Bacterial Metabolites. Cell 2016, 165, 1332-1345. [CrossRef]

122. Louis, P.; Young, P.; Holtrop, G.; Flint, H.J. Diversity of human colonic butyrate-producing bacteria revealed by analysis of the butyryl-CoA:acetate CoA-transferase gene. Environ. Microbiol. 2010, 12, 304-314. [CrossRef] [PubMed]

123. Kirkup, B.; McKee, A.; Makin, K.; Paveley, J.; Caim, S.; Alcon-Giner, C.; Leclaire, C.; Dalby, M.; Le Gall, G.; Andrusaite, A.; et al. Perturbation of the gut microbiota by antibiotics results in accelerated breast tumour growth and metabolic dysregulation. BioRxiv 2019. [CrossRef]

124. Gerard, P. Metabolism of cholesterol and bile acids by the gut microbiota. Pathogens 2013, 3, 14-24. [CrossRef] [PubMed]

125. Ridlon, J.M.; Harris, S.C.; Bhowmik, S.; Kang, D.J.; Hylemon, P.B. Consequences of bile salt biotransformations by intestinal bacteria. Gut Microbes. 2016, 7, 22-39. [CrossRef] [PubMed]

126. Long, S.L.; Gahan, C.G.M.; Joyce, S.A. Interactions between gut bacteria and bile in health and disease. Mol. Asp. Med. 2017, 56, 54-65. [CrossRef] [PubMed]

127. Hirano, S.; Masuda, N. Transformation of bile acids by Eubacterium lentum. Appl. Environ. Microbiol. 1981, 42, 912-915. [CrossRef]

128. Hirano, S.; Masuda, N.; Mukai, H.; Hirakawa, K.; Imamura, T. Transformation of bile acids by Bacteroides fragilis strains isolated from the human intestine (author's transl). Nihon Saikingaku Zasshi 1979, 34, 403-411. [CrossRef]

129. Salvioli, G.; Salati, R.; Bondi, M.; Fratalocchi, A.; Sala, B.M.; Gibertini, A. Bile acid transformation by the intestinal flora and cholesterol saturation in bile. Effects of Streptococcus faecium administration. Digestion 1982, 23, 80-88. [CrossRef]

130. Goodwin, A.C.; Destefano Shields, C.E.; Wu, S.; Huso, D.L.; Wu, X.; Murray-Stewart, T.R.; Hacker-Prietz, A.; Rabizadeh, S.; Woster, P.M.; Sears, C.L.; et al. Polyamine catabolism contributes to enterotoxigenic Bacteroides fragilis-induced colon tumorigenesis. Proc. Natl. Acad. Sci. USA 2011, 108, 15354-15359. [CrossRef]

131. Michael, A.J. Polyamine function in archaea and bacteria. J. Biol. Chem. 2018, 293, 18693-18701. [CrossRef]

132. De las Rivas, B.; Marcobal, A.; Carrascosa, A.V.; Munoz, R. PCR detection of foodborne bacteria producing the biogenic amines histamine, tyramine, putrescine, and cadaverine. J. Food Prot. 2006, 69, 2509-2514. [CrossRef] [PubMed]

133. Gao, J.; Xu, K.; Liu, H.; Liu, G.; Bai, M.; Peng, C.; Li, T.; Yin, Y. Impact of the Gut Microbiota on Intestinal Immunity Mediated by Tryptophan Metabolism. Front. Cell. Infect. Microbiol. 2018. [CrossRef] [PubMed]

134. Clausen, M.R.; Mortensen, P.B.; Bendtsen, F. Serum levels of short-chain fatty acids in cirrhosis and hepatic coma. Hepatology 1991, 14, 1040-1045. [CrossRef] [PubMed]

135. Jakobsdottir, G.; Bjerregaard, J.H.; Skovbjerg, H.; Nyman, M. Fasting serum concentration of short-chain fatty acids in subjects with microscopic colitis and celiac disease: No difference compared with controls, but between genders. Scand. J. Gastroenterol. 2013, 48, 696-701. [CrossRef] [PubMed]

136. Ktsoyan, Z.A.; Mkrtchyan, M.S.; Zakharyan, M.K.; Mnatsakanyan, A.A.; Arakelova, K.A.; Gevorgyan, Z.U.; Sedrakyan, A.M.; Hovhannisyan, A.I.; Arakelyan, A.A.; Aminov, R.I. Systemic Concentrations of Short Chain Fatty Acids Are Elevated in Salmonellosis and Exacerbation of Familial Mediterranean Fever. Front. Microbiol. 2016, 7, 776. [CrossRef] [PubMed] 
137. Pryde, S.E.; Duncan, S.H.; Hold, G.L.; Stewart, C.S.; Flint, H.J. The microbiology of butyrate formation in the human colon. FEMS Microbiol. Lett. 2002, 217, 133-139. [CrossRef]

138. Ivan, J.; Major, E.; Sipos, A.; Kovacs, K.; Horvath, D.; Tamas, I.; Bay, P.; Dombradi, V.; Lontay, B. The Short-Chain Fatty Acid Propionate Inhibits Adipogenic Differentiation of Human Chorion-Derived Mesenchymal Stem Cells Through the Free Fatty Acid Receptor 2. Stem Cells Dev. 2017, 26, 1724-1733. [CrossRef]

139. Fruge, A.D.; Van der Pol, W.; Rogers, L.Q.; Morrow, C.D.; Tsuruta, Y.; Demark-Wahnefried, W. Fecal Akkermansia muciniphila Is Associated with Body Composition and Microbiota Diversity in Overweight and Obese Women with Breast Cancer Participating in a Presurgical Weight Loss Trial. J. Acad. Nutr. Diet 2018, 9, 164. [CrossRef]

140. Fellows, R.; Varga-Weisz, P. Chromatin dynamics and histone modifications in intestinal microbiota-host crosstalk. Mol. Metab. 2019, 27, 30951-30956. [CrossRef]

141. Shimazu, T.; Hirschey, M.D.; Newman, J.; He, W.; Shirakawa, K.; Le Moan, N.; Grueter, C.A.; Lim, H.; Saunders, L.R.; Stevens, R.D.; et al. Suppression of oxidative stress by beta-hydroxybutyrate, an endogenous histone deacetylase inhibitor. Science 2013, 339, 211-214. [CrossRef]

142. Menzies, K.J.; Zhang, H.; Katsyuba, E.; Auwerx, J. Protein acetylation in metabolism-Metabolites and cofactors. Nat. Rev. Endocrinol. 2016, 12, 43-60. [CrossRef] [PubMed]

143. Haase, S.; Haghikia, A.; Wilck, N.; Muller, D.N.; Linker, R.A. Impacts of microbiome metabolites on immune regulation and autoimmunity. Immunology 2018, 154, 230-238. [CrossRef] [PubMed]

144. Ratajczak, W.; Ryl, A.; Mizerski, A.; Walczakiewicz, K.; Sipak, O.; Laszczynska, M. Immunomodulatory potential of gut microbiome-derived short-chain fatty acids (SCFAs). Acta Biochim. Pol. 2019, 66, 1-12. [CrossRef] [PubMed]

145. Kanika, G.; Khan, S.; Jena, G. Sodium Butyrate Ameliorates L-Arginine-Induced Pancreatitis and Associated Fibrosis in Wistar Rat: Role of Inflammation and Nitrosative Stress. J. Biochem. Mol. Toxicol. 2015, 29, 349-359. [CrossRef]

146. Bhagat, T.D.; Von Ahrens, D.; Dawlaty, M.; Zou, Y.; Baddour, J.; Achreja, A.; Zhao, H.; Yang, L.; Patel, B.; Kwak, C.; et al. Lactate-mediated epigenetic reprogramming regulates formation of human pancreatic cancer-associated fibroblasts. Elife 2019. [CrossRef]

147. Mullins, T.D.; Kern, H.F.; Metzgar, R.S. Ultrastructural differentiation of sodium butyrate-treated human pancreatic adenocarcinoma cell lines. Pancreas 1991, 6, 578-587. [CrossRef]

148. Pellizzaro, C.; Speranza, A.; Zorzet, S.; Crucil, I.; Sava, G.; Scarlata, I.; Cantoni, S.; Fedeli, M.; Coradini, D. Inhibition of human pancreatic cell line MIA PaCa2 proliferation by HA-But, a hyaluronic butyric ester: A preliminary report. Pancreas 2008, 36, e15-e23. [CrossRef]

149. Iwahashi, S.; Ishibashi, H.; Utsunomiya, T.; Morine, Y.; Ochir, T.L.; Hanaoka, J.; Mori, H.; Ikemoto, T.; Imura, S.; Shimada, M. Effect of histone deacetylase inhibitor in combination with 5-fluorouracil on pancreas cancer and cholangiocarcinoma cell lines. J. Med. Investig. 2011, 58, 106-109. [CrossRef]

150. Norlin, M.; Wikvall, K. Enzymes in the conversion of cholesterol into bile acids. Curr. Mol. Med. 2007, 7, 199-218. [CrossRef]

151. Ridlon, J.M.; Kang, D.J.; Hylemon, P.B. Bile salt biotransformations by human intestinal bacteria. J. Lipid. Res. 2006, 47, 241-259. [CrossRef]

152. Wahlstrom, A.; Sayin, S.I.; Marschall, H.U.; Backhed, F. Intestinal Crosstalk between Bile Acids and Microbiota and Its Impact on Host Metabolism. Cell Metab. 2016, 24, 41-50. [CrossRef] [PubMed]

153. Midtvedt, T. Microbial bile acid transformation. Am. J. Clin. Nutr. 1974, 27, 1341-1347. [CrossRef] [PubMed]

154. Marshall, W.J.; Lapsley, M.; Day, A. Clinical Chemistry, 8th ed.; Elsevier: Amsterdam, The Netherlands, 2016.

155. Watanabe, M.; Houten, S.M.; Mataki, C.; Christoffolete, M.A.; Kim, B.W.; Sato, H.; Messaddeq, N.; Harney, J.W.; Ezaki, O.; Kodama, T.; et al. Bile acids induce energy expenditure by promoting intracellular thyroid hormone activation. Nature 2006, 439, 484-489. [CrossRef]

156. MahmoudianDehkordi, S.; Arnold, M.; Nho, K.; Ahmad, S.; Jia, W.; Xie, G.; Louie, G.; Kueider-Paisley, A.; Moseley, M.A.; Thompson, J.W.; et al. Altered bile acid profile associates with cognitive impairment in Alzheimer's disease-An emerging role for gut microbiome. Alzheimers Dement. 2019, 15, 76-92. [CrossRef] [PubMed]

157. Sarin, S.K.; Pande, A.; Schnabl, B. Microbiome as a therapeutic target in alcohol-related liver disease. J. Hepatol. 2019, 70, 260-272. [CrossRef] [PubMed] 
158. McIlvride, S.; Dixon, P.H.; Williamson, C. Bile acids and gestation. Mol. Asp. Med. 2017, 56, 90-100. [CrossRef] [PubMed]

159. Houten, S.M.; Watanabe, M.; Auwerx, J. Endocrine functions of bile acids. EMBO J. 2006, 25, 1419-1425. [CrossRef]

160. Tsuei, J.; Chau, T.; Mills, D.; Wan, Y.J. Bile acid dysregulation, gut dysbiosis, and gastrointestinal cancer. Exp. Biol. Med. 2014, 239, 1489-1504. [CrossRef]

161. Rowland, I.R. (Ed.) The Role of the Gut Flora in Toxicity and Cancer; Academic Press: Carshalton, UK, 1988.

162. Goldberg, A.A.; Titorenko, V.I.; Beach, A.; Sanderson, J.T. Bile acids induce apoptosis selectively in androgen-dependent and -independent prostate cancer cells. PeerJ 2013, 1, e122. [CrossRef]

163. Gafar, A.A.; Draz, H.M.; Goldberg, A.A.; Bashandy, M.A.; Bakry, S.; Khalifa, M.A.; AbuShair, W.; Titorenko, V.I.; Sanderson, J.T. Lithocholic acid induces endoplasmic reticulum stress, autophagy and mitochondrial dysfunction in human prostate cancer cells. PeerJ 2016, 4, e2445. [CrossRef]

164. Goldberg, A.A.; Beach, A.; Davies, G.F.; Harkness, T.A.; Leblanc, A.; Titorenko, V.I. Lithocholic bile acid selectively kills neuroblastoma cells, while sparing normal neuronal cells. Oncotarget 2011, 2, 761-782. [CrossRef] [PubMed]

165. Blanchet, M.; Brunel, J.M. Bile Acid Derivatives: From Old Molecules to a New Potent Therapeutic Use: An Overview. Curr. Med. Chem. 2018, 25, 3613-3636. [CrossRef] [PubMed]

166. Phelan, J.P.; Reen, F.J.; Dunphy, N.; O'Connor, R.; O'Gara, F. Bile acids destabilise HIF-1alpha and promote anti-tumour phenotypes in cancer cell models. BMC Cancer 2016. [CrossRef] [PubMed]

167. Phelan, J.P.; Reen, F.J.; Caparros-Martin, J.A.; O'Connor, R.; O'Gara, F. Rethinking the bile acid/gut microbiome axis in cancer. Oncotarget 2017, 8, 115736-115747. [CrossRef]

168. Shellman, Z.; Aldhahrani, A.; Verdon, B.; Mather, M.; Paleri, V.; Wilson, J.; Pearson, J.; Ward, C.; Powell, J. Bile acids: A potential role in the pathogenesis of pharyngeal malignancy. Clin. Otolaryngol. 2017, 42, 969-973. [CrossRef]

169. Luu, T.H.; Bard, J.M.; Carbonnelle, D.; Chaillou, C.; Huvelin, J.M.; Bobin-Dubigeon, C.; Nazih, H. Lithocholic bile acid inhibits lipogenesis and induces apoptosis in breast cancer cells. Cell. Oncol. 2018, 41, 13-24. [CrossRef]

170. Merritt, M.E.; Donaldson, J.R. Effect of bile salts on the DNA and membrane integrity of enteric bacteria. J. Med. Microbiol. 2009, 58, 1533-1541. [CrossRef]

171. Garcia-Quintanilla, M.; Prieto, A.I.; Barnes, L.; Ramos-Morales, F.; Casadesus, J. Bile-induced curing of the virulence plasmid in Salmonella enterica serovar Typhimurium. J. Bacteriol. 2006, 188, 7963-7965. [CrossRef]

172. Prieto, A.I.; Ramos-Morales, F.; Casadesus, J. Repair of DNA damage induced by bile salts in Salmonella enterica. Genetics 2006, 174, 575-584. [CrossRef]

173. Prieto, A.I.; Ramos-Morales, F.; Casadesus, J. Bile-induced DNA damage in Salmonella enterica. Genetics 2004, 168, 1787-1794. [CrossRef]

174. Kandell, R.L.; Bernstein, C. Bile salt/acid induction of DNA damage in bacterial and mammalian cells: Implications for colon cancer. Nutr. Cancer 1991, 16, 227-238. [CrossRef] [PubMed]

175. Schaffler, H.; Breitruck, A. Clostridium difficile-From Colonization to Infection. Front. Microbiol. 2018, 9. [CrossRef] [PubMed]

176. Sorg, J.A.; Sonenshein, A.L. Inhibiting the initiation of Clostridium difficile spore germination using analogs of chenodeoxycholic acid, a bile acid. J. Bacteriol. 2010, 192, 4983-4990. [CrossRef] [PubMed]

177. Slocum, M.M.; Sittig, K.M.; Specian, R.D.; Deitch, E.A. Absence of intestinal bile promotes bacterial translocation. Am. Surg. 1992, 58, 305-310.

178. Rees, D.O.; Crick, P.J.; Jenkins, G.J.; Wang, Y.; Griffiths, W.J.; Brown, T.H.; Al-Sarireh, B. Comparison of the composition of bile acids in bile of patients with adenocarcinoma of the pancreas and benign disease. J. Steroid. Biochem. Mol. Biol. 2017, 174, 290-295. [CrossRef]

179. Feng, H.Y.; Chen, Y.C. Role of bile acids in carcinogenesis of pancreatic cancer: An old topic with new perspective. World J. Gastroenterol. 2016, 22, 7463-7477. [CrossRef]

180. Gandhi, D.; Ojili, V.; Nepal, P.; Nagar, A.; Hernandez-Delima, F.J.; Bajaj, D.; Choudhary, G.; Gupta, N.; Sharma, P. A pictorial review of gall stones and its associated complications. Clin. Imaging 2019, 60, 228-236. [CrossRef]

181. Fu, H.; Li, Y.; Bai, G.; Yin, R.; Yin, C.; Shi, W.; Zhang, L.; Li, R.; Zhao, R. Persistent cholestasis resulting from duodenal papillary carcinoma in an adolescent male: A case report. Medicine 2019, 98, e15708. [CrossRef] 
182. Thomas, R.M.; Jobin, C. Microbiota in pancreatic health and disease: The next frontier in microbiome research. Nat. Rev. Gastroenterol. Hepatol. 2020, 17, 53-64. [CrossRef]

183. Bernstein, C.; Bernstein, H.; Payne, C.M.; Dvorak, K.; Garewal, H. Field defects in progression to gastrointestinal tract cancers. Cancer Lett. 2008, 260, 1-10. [CrossRef]

184. Tucker, O.N.; Dannenberg, A.J.; Yang, E.Y.; Fahey Iii, T.J. Bile acids induce cyclooxygenase-2 expression in human pancreatic cancer cell lines. Carcinogenesis 2004, 25, 419-423. [CrossRef] [PubMed]

185. Adachi, T.; Tajima, Y.; Kuroki, T.; Mishima, T.; Kitasato, A.; Fukuda, K.; Tsutsumi, R.; Kanematsu, T. Bile-reflux into the pancreatic ducts is associated with the development of intraductal papillary carcinoma in hamsters. J. Surg. Res. 2006, 136, 106-111. [CrossRef] [PubMed]

186. Ura, H.; Makino, T.; Ito, S.; Tsutsumi, M.; Kinugasa, T.; Kamano, T.; Ichimiya, H.; Konishi, Y. Combined effects of cholecystectomy and lithocholic acid on pancreatic carcinogenesis of N-nitrosobis(2-hydroxypropyl)amine in Syrian golden hamsters. Cancer Res. 1986, 46, 4782-4786. [PubMed]

187. Nagathihalli, N.S.; Beesetty, Y.; Lee, W.; Washington, M.K.; Chen, X.; Lockhart, A.C.; Merchant, N.B. Novel mechanistic insights into ectodomain shedding of EGFR Ligands Amphiregulin and TGF- $\alpha$ : Impact on gastrointestinal cancers driven by secondary bile acids. Cancer Res. 2014, 74, 2062-2072. [CrossRef] [PubMed]

188. Kim, Y.J.; Jeong, S.H.; Kim, E.K.; Kim, E.J.; Cho, J.H. Ursodeoxycholic acid suppresses epithelial-mesenchymal transition and cancer stem cell formation by reducing the levels of peroxiredoxin II and reactive oxygen species in pancreatic cancer cells. Oncol. Rep. 2017, 38, 3632-3638. [CrossRef] [PubMed]

189. Hummel, D.; Aggarwal, A.; Borka, K.; Bajna, E.; Kallay, E.; Horvath, H.C. The vitamin D system is deregulated in pancreatic diseases. J. Steroid. Biochem. Mol. Biol. 2014, 144, 402-409. [CrossRef]

190. Chen, X.-L.; Xie, K.-X.; Yang, Z.-L.; Yuan, L.-W. Expression of FXR and HRG and their clinicopathological significance in benign and malignant pancreatic lesions. Int. J. Clin. Exp. Pathol. 2019, 12, 2111-2120.

191. Koutsounas, I.; Giaginis, C.; Alexandrou, P.; Zizi-Serbetzoglou, A.; Patsouris, E.; Kouraklis, G.; Theocharis, S. Pregnane X Receptor Expression in Human Pancreatic Adenocarcinoma: Associations With Clinicopathologic Parameters, Tumor Proliferative Capacity, Patients' Survival, and Retinoid X Receptor Expression. Pancreas 2015, 44, 1134-1140. [CrossRef]

192. Kashiwagi, K.; Yanagida, M.; Matsui, D.; Tanaka, M.; Sugimoto, K.; Chen, H.; Ichikawa-Tomikawa, N.; Marubashi, S.; Suzuki, H.; Chiba, H. Expression of liver X receptors in normal and refractory carcinoma tissues of the human lung and pancreas. Histol. Histopathol. 2018, 33, 497-505.

193. Saraswat, M.; Joenvaara, S.; Seppanen, H.; Mustonen, H.; Haglund, C.; Renkonen, R. Comparative proteomic profiling of the serum differentiates pancreatic cancer from chronic pancreatitis. Cancer Med. 2017, 6, 1738-1751. [CrossRef]

194. Candelaria, N.R.; Addanki, S.; Zheng, J.; Nguyen-Vu, T.; Karaboga, H.; Dey, P.; Gabbi, C.; Vedin, L.-L.; Liu, K.; $\mathrm{Wu}, \mathrm{W}$; et al. Antiproliferative effects and mechanisms of liver $\mathrm{X}$ receptor ligands in pancreatic ductal adenocarcinoma cells. PLoS ONE 2014, 9, e106289. [CrossRef] [PubMed]

195. Massaro, C.; Thomas, J.; Phanstiel Iv, O. Investigation of Polyamine Metabolism and Homeostasis in Pancreatic Cancers. Med. Sci. 2017, 5. [CrossRef]

196. Gitto, S.B.; Pandey, V.; Oyer, J.L.; Copik, A.J.; Hogan, F.C.; Phanstiel, O.T.; Altomare, D.A. Difluoromethylornithine Combined with a Polyamine Transport Inhibitor Is Effective against Gemcitabine Resistant Pancreatic Cancer. Mol. Pharm. 2018, 15, 369-376. [CrossRef] [PubMed]

197. Mohammed, A.; Janakiram, N.B.; Madka, V.; Ritchie, R.L.; Brewer, M.; Biddick, L.; Patlolla, J.M.; Sadeghi, M.; Lightfoot, S.; Steele, V.E.; et al. Eflornithine (DFMO) prevents progression of pancreatic cancer by modulating ornithine decarboxylase signaling. Cancer Prev. Res. 2014, 7, 1198-1209. [CrossRef]

198. Saydjari, R.; Alexander, R.W.; Barranco, S.C.; Townsend, C.M., Jr.; Thompson, J.C. The effects of 2-deoxy-D-glucose and alpha-difluoromethylornithine on the growth of pancreatic cancer in vivo. Pancreas 1989, 4, 38-43. [CrossRef]

199. Chang, B.K.; Gutman, R.; Black, O., Jr. Combined effects of alpha-difluoromethylornithine and doxorubicin against pancreatic cancer cell lines in culture. Pancreas 1986, 1, 49-54. [CrossRef]

200. Chang, B.K.; Bergeron, R.J.; Porter, C.W.; Liang, Y. Antitumor effects of N-alkylated polyamine analogues in human pancreatic adenocarcinoma models. Cancer Chemother. Pharmacol. 1992, 30, 179-182. [CrossRef]

201. Wortham, B.W.; Patel, C.N.; Oliveira, M.A. Polyamines in bacteria: Pleiotropic effects yet specific mechanisms. Adv. Exp. Med. Biol. 2007, 603, 106-115. [CrossRef] 
202. Miller-Fleming, L.; Olin-Sandoval, V.; Campbell, K.; Ralser, M. Remaining Mysteries of Molecular Biology: The Role of Polyamines in the Cell. J. Mol. Biol. 2015, 427, 3389-3406. [CrossRef]

203. Seiler, N. Catabolism of polyamines. Amino Acids 2004, 26, 217-233. [CrossRef]

204. Lu, Y.-C.; Yeh, W.-C.; Ohashi, P.S. LPS/TLR4 signal transduction pathway. Cytokine 2008, 42, $145-151$. [CrossRef] [PubMed]

205. Bertani, B.; Ruiz, N. Function and Biogenesis of Lipopolysaccharides. EcoSal Plus 2018, 8. [CrossRef] [PubMed]

206. Yokoyama, M.T.; Carlson, J.R. Microbial metabolites of tryptophan in the intestinal tract with special reference to skatole. Am. J. Clin. Nutr. 1979, 32, 173-178. [CrossRef] [PubMed]

207. Wikoff, W.R.; Anfora, A.T.; Liu, J.; Schultz, P.G.; Lesley, S.A.; Peters, E.C.; Siuzdak, G. Metabolomics analysis reveals large effects of gut microflora on mammalian blood metabolites. Proc. Natl. Acad. Sci. USA 2009, 106, 3698-3703. [CrossRef] [PubMed]

208. Browne, C.A.; Clarke, G.; Dinan, T.G.; Cryan, J.F. An effective dietary method for chronic tryptophan depletion in two mouse strains illuminates a role for 5-HT in nesting behaviour. Neuropharmacology 2012, 62, 1903-1915. [CrossRef] [PubMed]

209. El Aidy, S.; Kunze, W.; Bienenstock, J.; Kleerebezem, M. The microbiota and the gut-brain axis: Insights from the temporal and spatial mucosal alterations during colonisation of the germfree mouse intestine. Benef. Microbes. 2012, 3, 251-259. [CrossRef]

210. Mardinoglu, A.; Shoaie, S.; Bergentall, M.; Ghaffari, P.; Zhang, C.; Larsson, E.; Backhed, F.; Nielsen, J. The gut microbiota modulates host amino acid and glutathione metabolism in mice. Mol. Syst. Biol. 2015, 11, 834. [CrossRef]

211. Roager, H.M.; Licht, T.R. Microbial tryptophan catabolites in health and disease. Nat. Commun. 2018, 9, 3294. [CrossRef]

212. DeMoss, R.D.; Moser, K. Tryptophanase in diverse bacterial species. J. Bacteriol. 1969, 98, 167-171. [CrossRef]

213. Ma, Q.; Zhang, X.; Qu, Y. Biodegradation and Biotransformation of Indole: Advances and Perspectives. Front. Microbiol. 2018, 9, 2625. [CrossRef]

214. Zelante, T.; Iannitti, R.G.; Cunha, C.; De Luca, A.; Giovannini, G.; Pieraccini, G.; Zecchi, R.; D'Angelo, C.; Massi-Benedetti, C.; Fallarino, F.; et al. Tryptophan catabolites from microbiota engage aryl hydrocarbon receptor and balance mucosal reactivity via interleukin-22. Immunity 2013, 39, 372-385. [CrossRef] [PubMed]

215. Venkatesh, M.; Mukherjee, S.; Wang, H.; Li, H.; Sun, K.; Benechet, A.P.; Qiu, Z.; Maher, L.; Redinbo, M.R.; Phillips, R.S.; et al. Symbiotic bacterial metabolites regulate gastrointestinal barrier function via the xenobiotic sensor PXR and Toll-like receptor 4. Immunity 2014, 41, 296-310. [CrossRef] [PubMed]

216. Lamas, B.; Richard, M.L.; Leducq, V.; Pham, H.P.; Michel, M.L.; Da Costa, G.; Bridonneau, C.; Jegou, S.; Hoffmann, T.W.; Natividad, J.M.; et al. CARD9 impacts colitis by altering gut microbiota metabolism of tryptophan into aryl hydrocarbon receptor ligands. Nat. Med. 2016, 22, 598-605. [CrossRef] [PubMed]

217. Kim, C.H. Immune regulation by microbiome metabolites. Immunology 2018, 154, 220-229. [CrossRef]

218. Sonner, J.K.; Keil, M.; Falk-Paulsen, M.; Mishra, N.; Rehman, A.; Kramer, M.; Deumelandt, K.; Rowe, J.; Sanghvi, K.; Wolf, L.; et al. Dietary tryptophan links encephalogenicity of autoreactive T cells with gut microbial ecology. Nat. Commun. 2019, 10, 4877. [CrossRef]

219. Shi, L.Z.; Faith, N.G.; Nakayama, Y.; Suresh, M.; Steinberg, H.; Czuprynski, C.J. The aryl hydrocarbon receptor is required for optimal resistance to Listeria monocytogenes infection in mice. J. Immunol. 2007, 179, 6952-6962. [CrossRef]

220. Qiu, J.; Heller, J.J.; Guo, X.; Chen, Z.-m.E.; Fish, K.; Fu, Y.-X.; Zhou, L. The aryl hydrocarbon receptor regulates gut immunity through modulation of innate lymphoid cells. Immunity 2012, 36, 92-104. [CrossRef]

221. Zhang, L.; Nichols, R.G.; Patterson, A.D. The aryl hydrocarbon receptor as a moderator of host-microbiota communication. Curr. Opin. Toxicol. 2017, 2, 30-35. [CrossRef]

222. Jin, U.H.; Kim, S.B.; Safe, S. Omeprazole Inhibits Pancreatic Cancer Cell Invasion through a Nongenomic Aryl Hydrocarbon Receptor Pathway. Chem. Res. Toxicol. 2015, 28, 907-918. [CrossRef]

223. Ansari, D.; Toren, W.; Zhou, Q.; Hu, D.; Andersson, R. Proteomic and genomic profiling of pancreatic cancer. Cell Biol. Toxicol. 2019, 35, 333-343. [CrossRef]

224. Brown, J.M.; Hazen, S.L. Targeting of microbe-derived metabolites to improve human health: The next frontier for drug discovery. J. Biol. Chem. 2017, 292, 8560-8568. [CrossRef] [PubMed] 
225. Descamps, H.C.; Herrmann, B.; Wiredu, D.; Thaiss, C.A. The path toward using microbial metabolites as therapies. EBioMedicine 2019, 44, 747-754. [CrossRef] [PubMed]

226. Szanto, M.; Dozsa, A.; Antal, D.; Szabo, K.; Kemeny, L.; Bai, P. Targeting the gut-skin axis-Probiotics as new tools for skin disorder management? Exp. Dermatol. 2019. [CrossRef] [PubMed]

227. Velicer, C.M.; Heckbert, S.R.; Lampe, J.W.; Potter, J.D.; Robertson, C.A.; Taplin, S.H. Antibiotic use in relation to the risk of breast cancer. JAMA 2004, 291, 827-835. [CrossRef] [PubMed]

228. Varian, B.J.; Goureshetti, S.; Poutahidis, T.; Lakritz, J.R.; Levkovich, T.; Kwok, C.; Teliousis, K.; Ibrahim, Y.M.; Mirabal, S.; Erdman, S.E. Beneficial bacteria inhibit cachexia. Oncotarget 2016, 7, 11803-11816. [CrossRef]

229. Mills, S.; Stanton, C.; Lane, J.A.; Smith, G.J.; Ross, R.P. Precision Nutrition and the Microbiome, Part I: Current State of the Science. Nutrients 2019, 11, 923. [CrossRef]

(C) 2020 by the authors. Licensee MDPI, Basel, Switzerland. This article is an open access article distributed under the terms and conditions of the Creative Commons Attribution (CC BY) license (http://creativecommons.org/licenses/by/4.0/). 